\title{
Matlab/simulink simulation of unified power quality conditioner-battery energy storage system supplied by PV-wind hybrid using fuzzy logic controller
}

\author{
Amirullah $^{1}$, Ontoseno Penangsang ${ }^{2}$, Adi Soeprijanto ${ }^{3}$ \\ 1,2,3 Department of Electrical Engineering, Faculty of Electrical Technology, ITS Surabaya, Indonesia \\ ${ }^{1}$ Study Program of Electrical Engineering, Faculty of Engineering, University of Bhayangkara Surabaya, Indonesia
}

\begin{tabular}{l} 
Article Info \\
\hline Article history: \\
Received May 2, 2018 \\
Revised Nov 11, 2018 \\
Accepted Dec 2, 2018 \\
\hline
\end{tabular}

\section{Keywords:}

Battery energy storage

Photovoltaic

Power quality

PV-Wind Hybrid

Total harmonic distortion

UPQC

Wind turbine

\begin{abstract}
This paper presents performance analysis of Unified Power Quality Conditioner-Battery Energy Storage (UPQC-BES) system supplied by Photovoltaic (PV)-Wind Hybrid connected to three phase three wire (3P3W) of 380 volt (L-L) and 50 hertz distribution system. The performance of supply system is compared with two renewable energy (RE) sources i.e. PV and Wind, respectively. Fuzzy Logic Controller (FLC) is implemented to maintain DC voltage across the capacitor under disturbance scenarios of source and load as well as to compare the results with Proportional Intergral (PI) controller. There are six scenarios of disturbance i.e. (1) non-linear load (NL), (2) unbalance and nonlinear load (Unba-NL), (3) distortion supply and non-linear load (Dis-NL), (4) sag and non-linear load (Sag-NL), (5) swell and non-linear load (Swell-NL), and (6) interruption and non-linear load (InterNL). In disturbance scenario 1 to 5, implementation of FLC on UPQC-BES system supplied by three RE sources is able to obtain average THD of load voltage/source current slightly better than PI. Furthermore under scenario 6, FLC applied on UPQC-BES system supplied by three RE sources gives significantly better result of average THD of load voltage/source current than PI. This research is simulated using Matlab/Simulink.
\end{abstract}

Copyright () 2019Institute of Advanced Engineering and Science. All rights reserved.

\section{Corresponding Author:}

Amirullah,

Department of Electrical Engineering,

Institut Teknologi Sepuluh Nopember (ITS),

Kampus ITS Keputih, Sukolilo, Surabaya 60111, Indonesia.

Email: amirullah14@mhs.ee.its.ac.id, amirullah@ubhara.ac.id,am9520012003@yahoo.com

\section{INTRODUCTION}

PV and wind are the most RE distributed generations (DGs) because they are able to convert sunlight and wind into power. PV and solar are the potential DGs sources since it only need sunlight to generate electricity, where the resources are available in abundance, free and relatively clean. Indonesia has enormous energy potential from the sun because it lies on the equator. Almost all areas of Indonesia get sunlight about 10 to 12 hours per day, with an average intensity of irradiation of $4.5 \mathrm{kWh} / \mathrm{m}^{2}$ or equivalent to $112.000 \mathrm{GW}$. The potential of wind energy in Indonesia generally has a speed between 4 to $5 \mathrm{~m} / \mathrm{s}$ and classified as medium scale with potential capacity of 10 to $100 \mathrm{~kW}$. The weakness of PV and wind turbine besides able to generate power, they also produces a number voltage and current harmonics resulted by presence of several types of PV and wind turbine devices and power converters as well as to increase a number of non-linear loads connected to the grid,so finally resulting in the decrease in power quality.

In order to overcome and improve power quality due to presence of non-linear loads and integration of PV and wind turbine to grid, UPQC is a proposed. UPQC serves to compensate for source voltage quality problemsi.e. sag, swell unbalance, flicker, harmonics, and load current quality problems i.e. harmonics, 
unbalance, reactive currents, and neutral current. B. Han et. al and Vinod Khadkikar have investigated UPQC as one part of active power filter consisting of shunt and series active filters connected in parallel and serves as superior controller to overcome a number of power quality problems simultaneously. Series component has been responsible for reducing a number of interference on source side i.e. voltage sag/swell, flicker, unbalanced voltage, and harmonics. Shunt component has been responsible for addressing a current quality problems i.e. low power factor, load current harmonics, and unbalanced load. [1, 2]. UPQC based on RE has been investigated by some researchers. There are two methods used to overcome this problem i.e. using conventional and artificial intelligence. Shafiuzzaman K.K., et.al have proposed system includes a series inverter, shunt inverter, and a DG connected to a DC link through a rectifier using PI. The system was capable of increase source voltage quality i.e. sag and interruption and load current quality, as well as transfer of active power on/off grid mode [3]. The influence of DG on UPQC performance in reducing sag under conditions of some phase to ground faults to using DSTATCOM has been implemented by Norshafinash S., et.al. The DG was effective enough to help UPQC to improve sag [4]. It was connected in series with load resulting better sag mitigation compared to system without DG. Implementation of UPQC using UVTG method with PI to reduce sag, swell, voltage/current harmonics has been doneby S. N. Gohil, et.al. Simulation of voltage distortion was made by adding $5^{\text {th }}$ and $7^{\text {th }}$ harmonics at fundamental source voltage, resulting in a reduction of THD source current and THD load voltage [5].

UPQC supplied by PV panels using boost converter, PI, MPPT P and O, and p-q theory has been proposed by Yahia Bouzelata at.al [6]. The system was capable of compensate reactive power and reduce source current/load voltage harmonics, but did not discuss migitation of sag and interuption caused by PV penetration. Power quality enhancement of sag and source voltage harmonics on grid using UPQC supplied by PV array connected to DC link using PI compared with FLC has been done by Ramalengswara Rao, et.al. Combination of UPQC and PV using FLC can improve source voltage THD better than PI [7]. Amirullah et.al have researched a method for balancing current and line voltage, as a result of DGs of a single phase PV generator unit in randomly installed at homes through on a three phase four wire $220 \mathrm{kV}$ and $50 \mathrm{~Hz}$ distribution line using BES and three of single phase bidirectional inverter. Both devices was capable of reduce unbalanced line current/voltage, but both of them were also capable of increase current/voltage harmonics on PCC bus [8]. Power quality migitation of UPQC on microgrid supplied by PV and wind turbine has been implemented by K S Srikanth et. al. It resulted that PI and FLC was able to improve power quality and reduce distortion in output power [9]. The UPQC-wind turbine to provide active power to overcome low sag and interruption voltage to grid has been investigated by H.Toodeji, et.al. The model was used VSC as a rectifier on generator output and controlled so that maximum power desired can be generated by different speed wind turbines using PI [10]. The UPQC-wind turbine connected to UPQC DC link was implemented by M. Hosseinpour, et al. The proposed combination using PI was capable of compensate swell, interruption voltage, and reactive power both on on/off grid [11]. R.Bhavani, et, al have researched on UPQC controlled by FLC to improve power quality in a DFIG wind turbine connected grid. FLC can improve power quality i.e. sag voltage and load current harmonics better than PI [12]. Power quality enhancement on wind turbine and BES with PI connected grid on PCC bus using UPQC has been implemented by S.RajeshRajan, et al. BES was installed to maintain and stabilize active power supply under different wind speed [13].

This research will analyze UPQC-BES performance supplied by PV-wind hybrid connected to 3P3W of 380 volt (L-L) and 50 hertz distribution system. The performance of supply system is compared with two RE sources i.e. PV and Wind, respectively. BES serves to store excess energy produced by three RE sources and distribute it to load if necessary, to prevent interruption voltage, and to adjust charging and discharging of energy in battery. BES is also expected to store excess power produced by three RE combinations and use it as backup power. FLC is proposed and compared with PI to control variable of DC voltage and DC reference voltage input to generate reference current source in current hysteresis controller on shunt active filter. DC voltage controller in shunt active filter and series active filter is used to migitate power quality of load voltage and source current.Performance of two controllers are used to determine load voltage, source current, load voltage THD, and source current THD based on IEEE 519. This paper is presented as follow. Section 2 describes proposed method, model of UPQC-BES system supplied by three RE sources i.e. PV, wind, and PV-wind hybrid, simulation parameters, PV and PMSG wind turbine model, series and shunt active filter, as well as application of PI and FLC method for proposed model. Section 3 shows results and analysis about performance of THD analysis on the proposed model of three RE sources connected to DC link of UPQC-BES system using PI and FLC. In this section, six disturbance scenarios are presented and the results are verified with Matlab/Simulink. Finally, this paper in concluded in Section 4.

Int J Elec \& Comp Eng, Vol. 9, No. 3, June 2019 : 1479 - 1495 


\section{RESEARCH METHOD}

\subsection{Proposed method}

Figure 1 shows proposed model in this research. The RE sources based DGs used i.e. PV, Wind Turbine, and PV-Wind Turbine Hybrid connected to 3P3W distribution system with 380 volt (L-L) and $50 \mathrm{~Hz}$ frequency, through UPQC-BES system. PV array produce power under fixed temperature and radiation as well as connect to UPQC-DC link through a DC/DC boost converter. The maximum power point tracking (MPPT) method with Pertub and Observer $(\mathrm{P}$ and $\mathrm{O})$ algorithms helps $\mathrm{PV}$ produce maximum power and generate output voltage, as the input voltage for DC/DC boost converter. The converter serves to adjust duty-cycle value and output voltage of PV as its input voltage to produce an output voltage corresponding to UPQC DC link voltage. Wind turbine type used is a permanent magnetic synchronous generator (PMSG) with variable speed and fixed voltage which generating power and is connected to UPQC DC link circuit through AC/DC bridge rectifier. The rectifier helps to change AC PSMG stator output voltage to DC voltage through LC circuit that serves to filter and smooth it before connected to UPQC-DC link.BES connected to the UPQC-DC link circuit serves as energy storage and is expected to overcome interruption voltage and overall help UPQC performance to improve voltage and current quality on source and load bus. Simulation parameters proposed in this study is shown in Appendix Section. Power quality analysis is performed on PV, Wind, PV-Wind Hybrid respectively, connected to 3P3W system through UPQC DC-link (on-grid) using BES circuit. Single phase circuit breakers $(\mathrm{CBs})$ are used to connect and disconnect PV, Wind, and Hybrid PV-Wind respectively with UPQC DC-link.

There are six disturbance scenarios i.e. (1) NL, (2) Unba-NL, (3) Dis-NL, (4) Sag-NL, (5) Swell-NL, and (6) Inter-NL. In scenario 1 , the model is connected a non-linear load with $\mathrm{R}_{\mathrm{L}}$ and $\mathrm{L}_{\mathrm{L}}$ of 60 Ohm and 0.15 $\mathrm{mH}$ respectively. In scenario 2 , the model is connected to non-linear load and during $0.3 \mathrm{~s}$ since $\mathrm{t}=0.2 \mathrm{~s}$ to $\mathrm{t}=0.5$ s connected to unbalance three phase load with $\mathrm{R}_{1}, \mathrm{R}_{2}, \mathrm{R}_{3}$ as $6 \mathrm{Ohm}, 12 \mathrm{Ohm}, 24 \mathrm{Ohm}$ respectively, and value of $\mathrm{C}_{1}, \mathrm{C}_{2}, \mathrm{C}_{3}$ as $2200 \mu \mathrm{F}$. In scenario 3 , the model is connected to non-linear load and source voltage generating $5^{\text {th }}$ and $7^{\text {th }}$ harmonic components with individual harmonic distortion values of $5 \%$ and $2 \%$ respectively. In scenario 4, the model is connected to non-linear load and source experiences a sag voltage disturbance of $50 \%$ for $0.3 \mathrm{~s}$ between $\mathrm{t}=0.2 \mathrm{~s}$ to $\mathrm{t}=0.5 \mathrm{~s}$. In scenario 5 , the model is connected to a non-linear load and source experiences a swell voltage disturbance of $50 \%$ for $0.3 \mathrm{~s}$ between $\mathrm{t}=0.2 \mathrm{~s}$ to $\mathrm{t}=0.5 \mathrm{~s}$. In scenario 6 , the model is connected to non-linear load and source experiences an interruption voltage interference of $100 \%$ for $0.3 \mathrm{~s}$ between $t=0.2 \mathrm{~s}$ to $\mathrm{t}=0.5 \mathrm{~s}$. FLC is used as a DC voltage control in a shunt active filter to improve the power quality of the load voltage and current source and compare it with PI controller. Each disturbance scenario uses a PI controller and FLC so that the total of 12 disturbances. The result analysis of research was carried out i.e. (1) voltage and current on source or poin common coupling (PCC) bus, (2) voltage and current on load bus, (3) harmonic voltage and harmonic current on source bus and (4) harmonic voltage and harmonic current on load bus. The final phase is to compare performance of UPQC-BES system on-grid supplied by PV, Wind, PV-Wind Hybrid respectively using two controllers to improve power quality of load voltage and source current under six disturbance conditions.

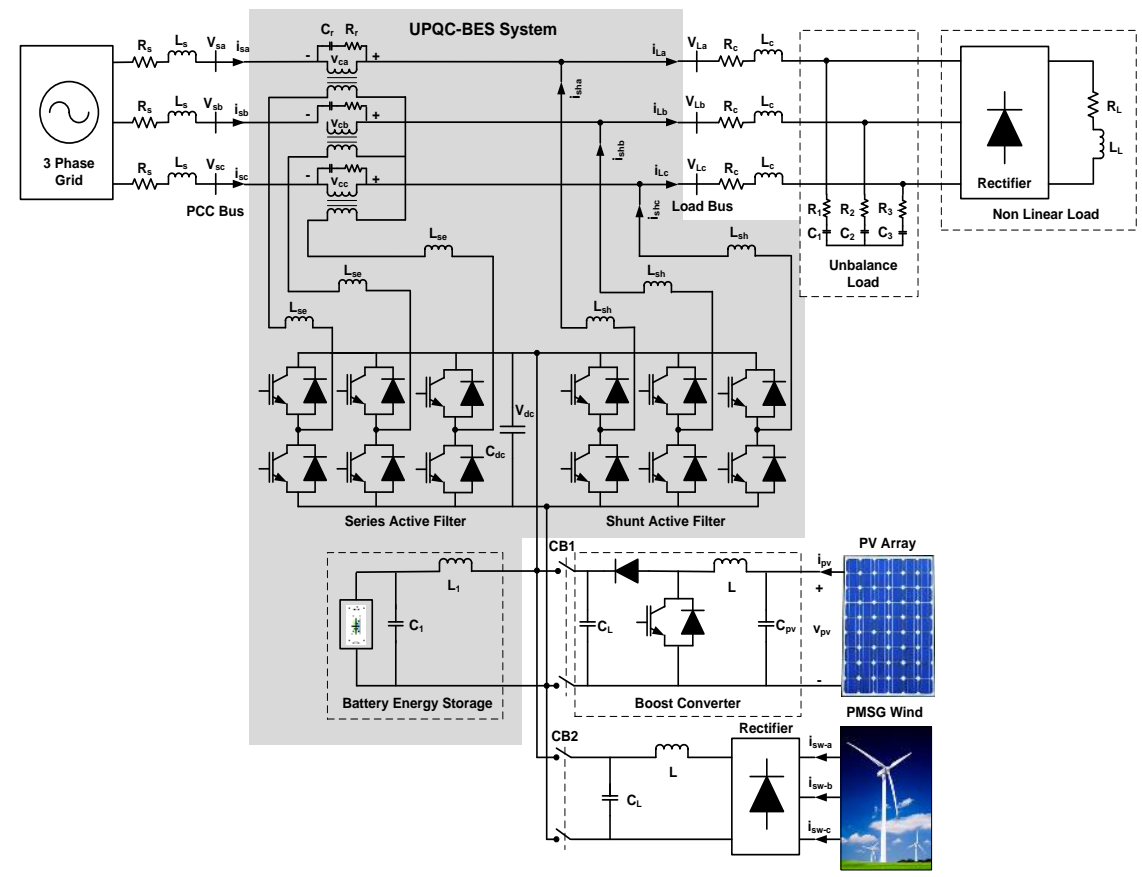

Figure 1. Proposed model of UPQC-BES system supplied by PV, Wind, and PV-Wind Hybrid

Matlab/simulink simulation of unified power quality conditioner-battery energy storage... (Amirullah) 


\subsection{Photovoltaic model}

Figure 2 shows the equivalent circuit and V-I characteristic of a solar panel. A solar panel is composed of several PV cells that have series, parallel, or series-parallel external connections [14].

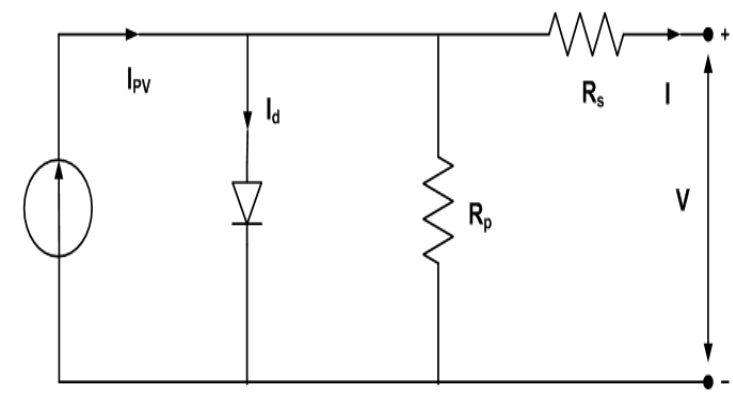

(a)

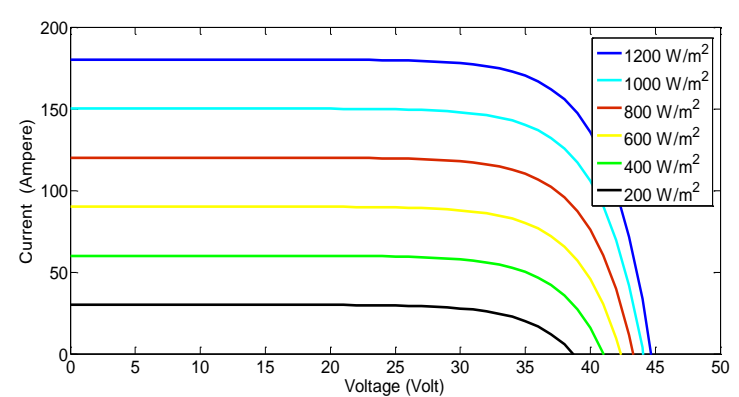

(b)

Figure 2. Equivalent circuit and V-I characteristic of solar panel

The V-I characteristic of a solar panel is showed in (1):

$$
I=I_{P V}-I_{o}\left[\exp \left(\frac{V+R_{S} I}{a V_{t}}\right)-1\right]-\frac{V+R_{S} I}{R_{P}}
$$

where $I_{P V}$ is the photovoltaic current, $I_{o}$ is saturated reverse current, ' $\mathrm{a}$ ' is the ideal diode constant, $V_{t}=N_{S} K T q^{-1}$ is the thermal voltage, $N_{S}$ is the number of series cells, $q$ is the electron charge, $K$ is the Boltzmann constant, $T$ is the temperature of $\mathrm{p}-\mathrm{n}$ junction, $R_{S}$ and $R_{P}$ are series and parallel equivalent resistance of the solar panels. $I_{P V}$ has a linear relation with light intensity and also varies with temperature variations. $I_{o}$ is dependent on temperature variations. The values of $I_{p v}$ and $I_{o}$ are calculated as following (2) and (3):

$$
\begin{aligned}
& I_{P V}=\left(I_{P V, n}+K_{1} \Delta T\right) \frac{G}{G_{n}} I \\
& I_{o}=\frac{I_{S C, n}+K_{I} \Delta T}{\exp \left(V_{O C, n}+K_{V} \Delta T\right) / a V_{t}-1}
\end{aligned}
$$

In which $I_{P V, n}, I_{S C, n}$ and $V_{O C, n}$ are photovoltaic current, short circuit current and open circuit voltage in standard conditions $\left(T_{n}=25 \mathrm{C}\right.$ and $\left.G_{n}=1000 \mathrm{Wm}^{-2}\right)$ respectively. $K_{I}$ is the coefficient of short circuit current to temperature, $\Delta T=T-T_{n}$ is the temperature deviation from standard temperature, $G$ is the light intensity and $K_{V}$ is the ratio coefficient of open circuit voltage to temperature. Open circuit voltage, short circuit current and voltage-current corresponding to the maximum power are three important points of I-V characteristic of solar panel. These points are changed by variations of atmospheric conditions. By using (4) and (5) which are derived from PV model equations, short circuit current and open circuit voltage can be calculated in different atmospheric conditions.

$$
\begin{aligned}
& I_{S C}=\left(I_{S C}+K_{1} \Delta T\right) \frac{G}{G_{n}} \\
& V_{O C}=V_{O C}+K_{V} \Delta T
\end{aligned}
$$

\subsection{PMSG wind turbine}

Wind turbine is one of part of an integrated system, which can be divided into two types i.e. fixed and variable speed wind turbines. In fixed speed type, rotating speed of turbine is fixed and hence, frequency of generated voltage remains constant, so it can be directly connected to the network. In this case, maximum power can not always be extracted by wind. On the other hand, on variable speed, turbine can rotate at different speeds, so maximum power can be generated in each wind speed by MPPT method [10]. The advantage of 
using a PMSG over a synchronous generator and DFIG machine because it has high efficiency and reliability. Due to the elimination of rotor external excitation, machine size, and cost also decreases, making PMSG to be more controlled easily with feedback control system. PMSG has become an attractive solution on wind generation systems with variable speed wind turbine applications [15]. Figure 3 and 4 shows model of PMSG wind turbine and wind turbin power characteristic curve.

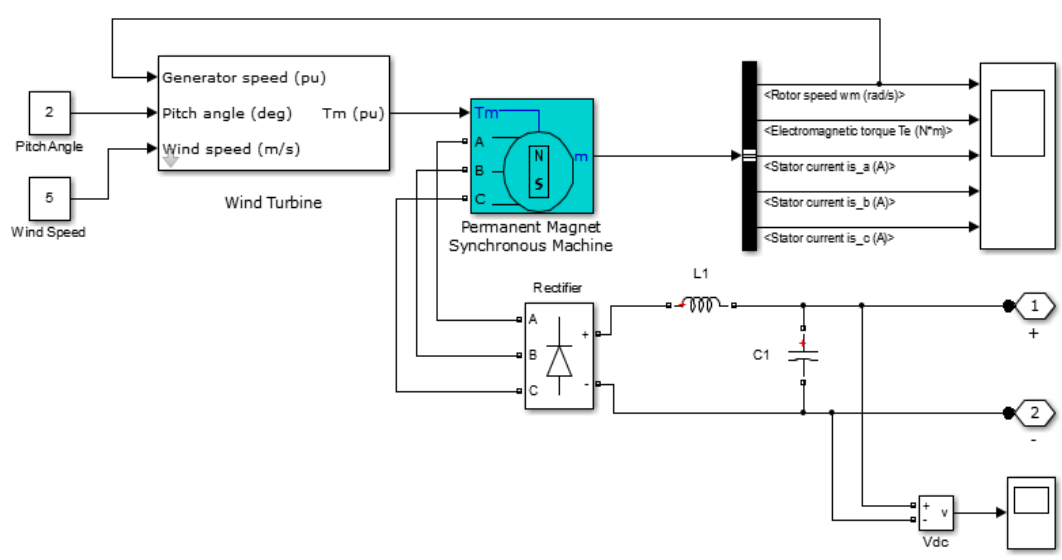

Figure 3. Model of PMSG wind turbine

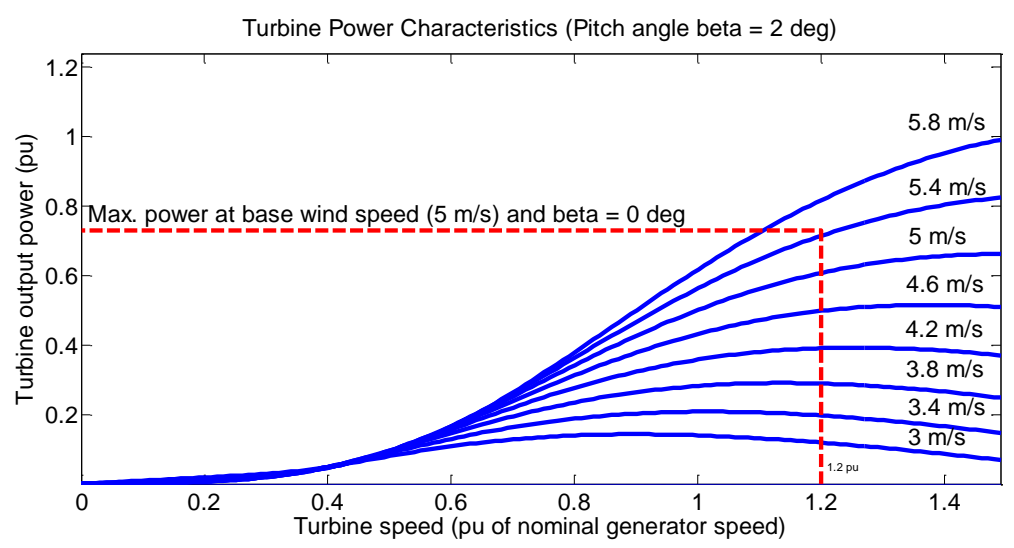

Figure 4. Wind turbin power characteristic curve

The output power of wind turbine can be expressed using (6), (7), and (8) [11].

$$
\begin{aligned}
& \lambda=\frac{\omega_{r} R}{V_{\text {wind }}} \\
& P_{M}=\frac{1}{2} \rho \pi R^{2} C_{p} V_{\text {wind }}^{3} \\
& T_{M}=\frac{P_{M}}{\omega_{r}}=\frac{1}{2} \rho \pi R^{5} C_{p} \frac{\omega_{M}^{3}}{\lambda^{3}}
\end{aligned}
$$

Where $\lambda$ is the speed-tip ratio, $\mathrm{V}_{\text {wind }}$ is wind speed, $\mathrm{R}$ is blade radius, $\omega_{\mathrm{r}}$ is rotor speed ( $\left.\mathrm{rad} / \mathrm{sec}\right), \rho$ is the air density, $\mathrm{C}_{\mathrm{P}}$ is the power coefficient, $\mathrm{P}_{\mathrm{M}}$ is the output mechanical power, and $\mathrm{T}_{\mathrm{M}}$ is output torque of wind turbine. The $C_{P}$ coefficient is dependent on the pitch angle value, at which rotor blade can rotate along axis and tipspeed ratio $\lambda$ expressed in (9). 


$$
C_{P}=(0.44-0.167 \beta) \sin \frac{\pi(\lambda-2)}{(13-0.3 \beta)}
$$

Where $\beta$ is a pitch angle blade. In a fixed pitch type, the value of $\beta$ is set to a fixed value.

\subsection{Control of series active filter}

The main function of series active filter is as a sensitive load protection against a number of voltage interference at PCC bus. The control strategy algorithm of the source and load voltage in series active filter circuit is shown in Figure 5. It extracts the unit vector templates from the distorted input supply. Furthermore, the templates are expected to be ideal sinusoidal signal with unity amplitude. The distorted supply voltages are measured and divided by peak amplitude of fundamental input voltage $V_{m}$ give in (10) [6].

$$
V_{m}=\sqrt{\frac{2}{3}\left(V_{s a}^{2}+V_{s b}^{2}+V_{s c}^{2}\right)}
$$

A three phase locked loop (PLL) is used in order to generate a sinusoidal unit vector templates with a phase lagging by the use of sinus function. The reference load voltage signal is determined by multiplying the unit vector templates with the peak amplitude of the fundamental input voltage $\mathrm{V}_{\mathrm{m}}$. The load reference voltage $\left(\mathrm{V}_{\mathrm{La}}{ }^{*}, \mathrm{~V}_{\mathrm{Lb}}{ }^{*}, \mathrm{~V}_{\mathrm{c}}{ }^{*}\right)$ is then compared against to sensed load voltage $\left(\mathrm{V}_{\mathrm{La}}, \mathrm{V}_{\mathrm{Lb}}, \mathrm{V}_{\mathrm{Lc}}\right)$ by a pulse width modulation $(\mathrm{PWM})$ controller used to generate the desired trigger signal on series active filter.

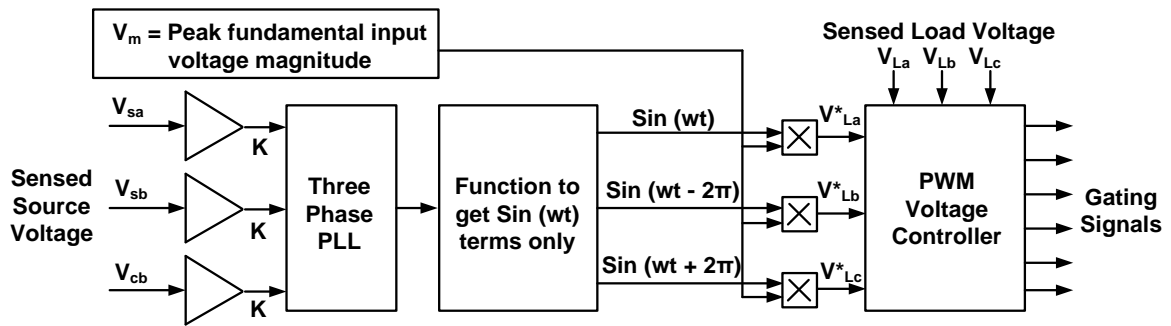

Figure 5. Control strategy of series active filter

\subsection{Control of shunt active filter}

The main function of shunt active filter is mitigation of power quality problems on the load side. The control methodology in shunt active filter is that the absorbed current from the PCC bus is a balanced positive sequence current including unbalanced sag voltage conditions in the PCC bus or unbalanced conditions or nonlinear loads. In order to obtain satisfactory compensation caesed by disturbance due to non-linear load, many algorithms have been used in the literature. This research used instantaneous reactive power theory method "p$\mathrm{q}$ theory". The voltages and currents in Cartesian $a b c$ coordinates can be transformed to Cartesian $\alpha \beta$ coordinates as expressed in (11) and (12) [16].

$$
\begin{aligned}
& {\left[\begin{array}{l}
v_{\alpha} \\
v_{\beta}
\end{array}\right]=\left[\begin{array}{ccc}
1 & -1 / 2 & -1 / 2 \\
1 & \sqrt{3} / 2 & -\sqrt{3} / 2
\end{array}\right]\left[\begin{array}{l}
V_{a} \\
V_{b} \\
V_{c}
\end{array}\right]} \\
& {\left[\begin{array}{l}
i_{\alpha} \\
i_{\beta}
\end{array}\right]=\left[\begin{array}{lll}
1 & -1 / 2 & -1 / 2 \\
1 & \sqrt{3} / 2 & -\sqrt{3} / 2
\end{array}\right]\left[\begin{array}{l}
i_{L a} \\
i_{L b} \\
i_{L c}
\end{array}\right]}
\end{aligned}
$$

The computation of the real power (p) and imaginary power $(q)$ is showed in (13). The real power and imaginary are measured instantaneously power and in matrix it is form is given as. The presence of oscillating and average components in instantaneous power is presented in (14) [17]. 


$$
\begin{aligned}
& {\left[\begin{array}{l}
p \\
q
\end{array}\right]=\left[\begin{array}{cc}
v_{\alpha} & v_{\beta} \\
-v_{\beta} & v_{\alpha}
\end{array}\right]\left[\begin{array}{l}
i_{\alpha} \\
i_{\beta}
\end{array}\right]} \\
& p=\bar{p}+\tilde{p} ; q=\bar{q}+\tilde{q}
\end{aligned}
$$

Where $\bar{p}=$ direct component of real power, $\widetilde{p}=$ fluctuating component of real power, $\bar{q}=$ direct component of imaginary power, $\tilde{q}=$ fluctuating component of imaginary power. The total imaginary power (q) and the fluctuating component of real power are selected as power references and current references and are utilized through the use of (15) for compensating harmonic and reactive power [18].

$$
\left[\begin{array}{l}
i_{c \alpha}^{*} \\
i_{c \beta}^{*}
\end{array}\right]=\frac{1}{v_{\alpha}^{2}+v_{\beta}^{2}}\left[\begin{array}{cc}
v_{\alpha} & v_{\beta} \\
v_{\beta} & -v_{\alpha}
\end{array}\right]\left[\begin{array}{l}
-\tilde{p}+\bar{p}_{\text {loss }} \\
-q
\end{array}\right]
$$

The signal $\bar{p}_{\text {loss }}$, is obtained from voltage regulator and is utilized as average real power. It can also be specified as the instantaneous active power which corresponds to the resistive loss and switching loss of the UPQC. The error obtained on comparing the actual DC-link capacitor voltage with the reference value is processed in FLC, engaged by voltage control loop as it minimizes the steady state error of the voltage across the DC link to zero. The compensating currents $\left(i_{c \alpha}^{*}, i_{c \beta}^{*}\right)$ as required to meet the power demand of load are shown in (15). These currents are represented in $\alpha-\beta$ coordinates. The phase current is required to acquire using (16) for compensation. These source phase currents $\left(i_{s a}^{*}, i_{s b}^{*}, i_{s c}^{*}\right)$ are represented in a-b-c axis obtained from the compensating current in the $\alpha-\beta$ coordinates presented in (16) [18]. Figure 6 shows a control of shunt active filter.

$$
\left[\begin{array}{l}
i_{s a}^{*} \\
i_{s b}^{*} \\
i_{s c}^{*}
\end{array}\right]=\sqrt{\frac{2}{3}}\left[\begin{array}{cc}
1 & 0 \\
-1 / 2 & \sqrt{3} / 2 \\
-1 / 2 & -\sqrt{3} / 2
\end{array}\right]\left[\begin{array}{l}
i_{c \alpha}^{*} \\
i_{c \beta}^{*}
\end{array}\right]
$$

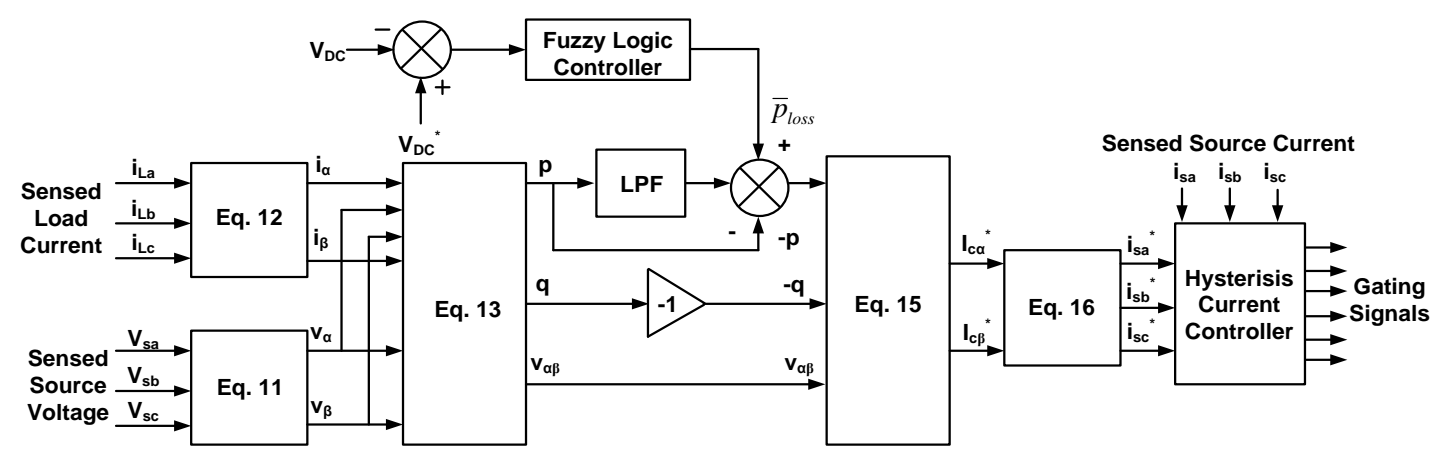

Figure 6. Control strategy of shunt active filter

The proposed model of UPQC-BES system supplied by three RE sources is shown in Figure 1. From the figure, we can see that PV is connected to the DC link through a DC-DC boost converter circuit. The PV partially distributes power to the load and the remains is transfered to three phase grid. The load consists of non linear and unbalanced load. The non-linear load is a diode rectifier circuit with the RL load type, while the unbalanced load is a three phase RC load with different $\mathrm{R}$ value on each phase. In order to economically efficient, PV must always work in MPP condition. In this research, MPPT method used is P and $\mathrm{O}$ algorithm. The model is also applied for UPQC-BES system which is supplied by wind and PV-wind hybrid respectively. In order to operate properly, UPQC-BES system device must have a minimum DC link voltage $\left(\mathrm{V}_{\mathrm{dc}}\right)$. The value of common DC link voltage depends on the nstantaneous energy avialable to UPQC is defined by in (17) [16]: 


$$
V_{d c}=\frac{2 \sqrt{2} V_{L L}}{\sqrt{3} m}
$$

where $m$ is modulation index and $\mathrm{V}_{\mathrm{LL}}$ is the $\mathrm{AC}$ grid line voltage of UPQC. Considering that modulation index as 1 and for line to line grid voltage $\left(\mathrm{V}_{\mathrm{LL}}=380\right.$ volt $)$, the $\mathrm{V}_{\mathrm{dc}}$ is obtained 620,54 volt and selected as 650 volt

The input of shunt active filter showed in Figure 5 is DC voltage $\left(\mathrm{V}_{\mathrm{dc}}\right)$ and reference DC voltage $\left(\mathrm{V}_{\mathrm{dc}}{ }^{*}\right)$, while the output is $\bar{p}_{\text {loss }}$ by using PI controller. Then, the $\bar{p}_{\text {loss }}$ is as one of input variable to generate the reference source current $\left(\mathrm{I}_{\mathrm{sa}}{ }^{*}, \mathrm{I}_{\mathrm{sb}}{ }^{*}\right.$, and $\left.\mathrm{I}_{\mathrm{sc}}{ }^{*}\right)$. The reference source current output is then compared to source current $\left(\mathrm{I}_{\mathrm{sa}}, \mathrm{I}_{\mathrm{sb}}\right.$, and $\left.\mathrm{I}_{\mathrm{sc}}\right)$ by the current hysteresis control to generate trigger signal in IGBT circuit of shunt active filter. In this research, FLC as DC voltage control algorithm on shunt active filter is proposed and compared with PI controller. The FLC is capable of reduce oscilation and generate quick convergence calculation during disturbances. This method is also used to overcome the weakness of PI controller in determining proportional gain $\left(\mathrm{K}_{\mathrm{p}}\right)$ and integral gain constant $\left(\mathrm{K}_{\mathrm{i}}\right)$ which still use trial and error method.

\subsection{Fuzzy logic controller}

The research is started by determine $\bar{p}_{\text {loss }}$ as the input variable to result the reference source current on current hysteresis controller to generate trigger signal on the IGBT shunt active filter of UPQC using PI controller $\left(\mathrm{K}_{\mathrm{p}}=0.2\right.$ and $\left.\mathrm{K}_{\mathrm{i}}=1.5\right)$. By using the same procedure, $\bar{p}_{\text {loss }}$ is also determined by using FLC. The FLC has been widely used in recent industrial process because it has heuristic, simpler, more effective and has multi rule based variables in both linear and non-linear system variations. The main components of FLC are fuzzification, decision making (rulebase, database, reason mechanism) and defuzzification in Figure 7. The output membership function is generated using inference blocks and the basic rules of FLC as shown in Table 1.

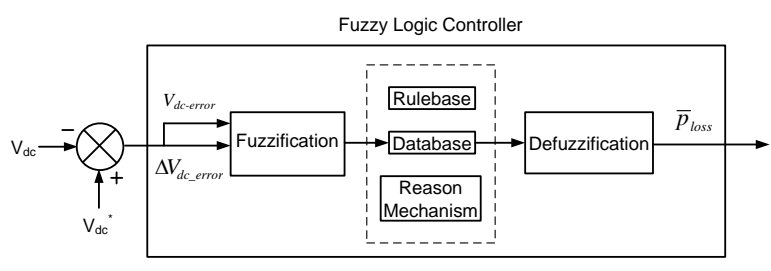

\begin{tabular}{cccccccc}
\multicolumn{8}{c}{ Table 1. Fuzzy Rule Base } \\
\hline $\begin{array}{c}\mathrm{V}_{\text {dc- }} \text { error } \\
\Delta \mathrm{V}_{\text {dc- }}\end{array}$ & NB & NM & NS & Z & PS & PM & PB \\
error & & & & & & & \\
\hline PB & Z & PS & PS & PM & PM & PB & PB \\
PM & NS & Z & PS & PS & PM & PM & PB \\
PS & NS & NS & Z & PS & PS & PM & PM \\
Z & NM & NS & NS & Z & PS & PS & PM \\
NS & NM & NM & NS & NS & Z & PS & PS \\
NM & NB & NM & NM & NS & NS & Z & PS \\
NB & NB & NB & NM & NM & NS & NS & Z \\
\hline
\end{tabular}

The fuzzy rule algorithm collects a number of fuzzy control rules in a particular order. This rule is used to control the system to meet the desired performance requirements and they are designed from a number of intelligent system control knowledge. The fuzzy inference of FLC using Mamdani method related to max-min composition. The fuzzy inference system in FLC consists of three parts: rule base, database, and reasoning mechanism [19]. The FLC method is performed by determining input variables $\mathrm{V}_{\mathrm{dc}}\left(\mathrm{V}_{\mathrm{dc} \text {-error }}\right)$ and delta $\mathrm{Vdc}$ $\left(\Delta \mathrm{V}_{\mathrm{dc} \text {-error }}\right)$, seven linguistic fuzzy sets, operation fuzzy block system (fuzzyfication, fuzzy rule base and defuzzification), $\mathrm{V}_{\mathrm{dc}-\text { error }}$ and $\Delta \mathrm{V}_{\mathrm{dc} \text {-error }}$ during fuzzification process, fuzzy rule base table, crisp value to determine $\bar{p}_{\text {loss }}$ in defuzzification phase. The $\bar{p}_{\text {loss }}$ is one of input variable to obtain compensating currents $\left(i_{c \alpha}^{*}, i_{c \beta}^{*}\right)$ in (16). During fuzzification process, a number of input variables are calculated and converted into linguistic variables based on a subset called membership function. The error $\mathrm{Vdc}\left(\mathrm{V}_{\mathrm{dc}-\mathrm{error}}\right)$ and delta error $\mathrm{Vdc}$ $\left(\Delta \mathrm{V}_{\text {dc-error }}\right)$ are proposed input variable system and output variable is $\bar{p}_{\text {loss }}$. To translate these variables, each input and output variable is designed using seven membership functions: Negative Big (NB), Negative Medium (NM), Negative Small (NS), Zero (Z), Positive Small (PS), Positive Medium (PM) and Positive Big (PB). The membership functions of crisp input and output are presented with triangular and trapezoidal membership functions. The value of $\mathrm{V}_{\text {dc-error }}$ range from -650 to $650, \Delta \mathrm{V}_{\text {dc-error }}$ from -650 to 650 , and $\bar{p}_{\text {loss }}$ from -100 to 100 . The input and output MFs are shown in Figure 8. 


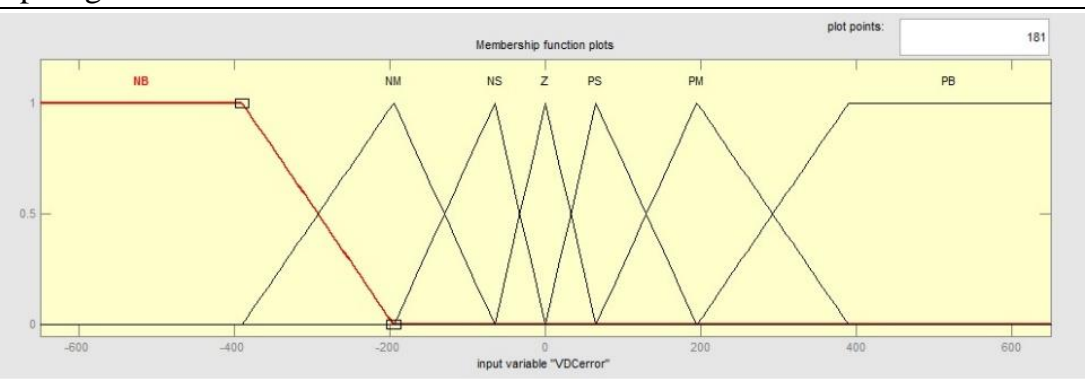

(a)

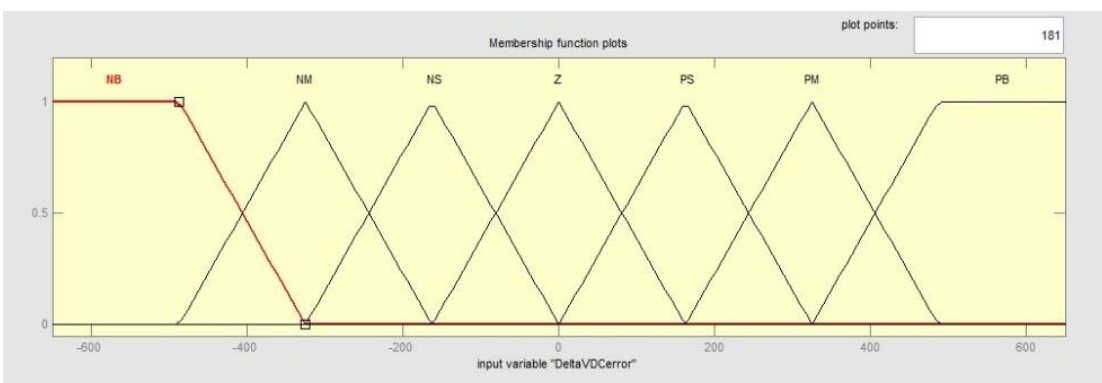

(b)

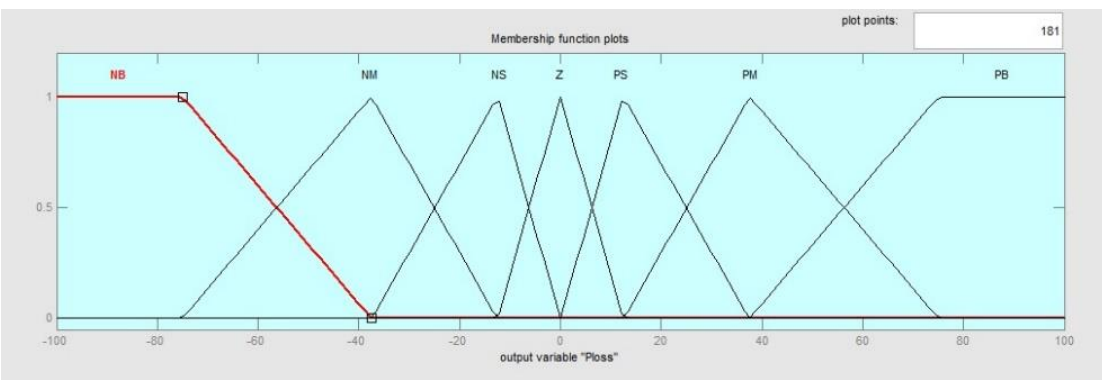

(c)

Figure 8. Membership functions (a) $\mathrm{V}_{\mathrm{dc}-\mathrm{error}}$, (b) $\Delta \mathrm{V}_{\mathrm{dc} \text {-error }}$, and (c) $\bar{p}_{\text {loss }}$

After the $\mathrm{V}_{\mathrm{dc}-\text { error }}$ and $\Delta \mathrm{V}_{\mathrm{dc} \text {-error }}$ are obtained, then two input membership functions are converted to linguistic variables and uses them as input functions for FLC. The output membership function is generated using inference blocks and the basic rules of FLC as shown in Table 1. Finally the defuzzification block operates to convert generated $\bar{p}_{\text {loss }}$ output from linguistic to numerical variable again. Then it becomes input variable for current hysteresis controller to produce trigger signal on the IGBT circuit of UPQC shunt active filter to reduce source current and load voltage harmonics. While simultaneously, it also improve power quality of 3P3W system under six scenarios due to the integration of three RE sources to UPQC-BES system.

\section{RESULTS AND ANALYSIS}

The analysis of proposed model is investigated through determination of six disturbance scenarios i.e. (1) NL, (2) Unba-NL, (3) Dis-NL, (4) Sag-NL, (5) Swell-NL, and (6) Inter-NL. Each scenario of UPQC uses PI controller and FLC so total number of disturbance are 12 scenarios. By using Matlab/Simulink, the model is then executed according to the desired scenario to obtain curve of source voltage $\left(\mathrm{V}_{\mathrm{s}}\right)$, load voltage $\left(\mathrm{V}_{\mathrm{L}}\right)$, compensation voltage $\left(\mathrm{V}_{\mathrm{c}}\right)$, source current $\left(\mathrm{V}_{\mathrm{s}}\right)$, load current $\left(\mathrm{I}_{\mathrm{L}}\right)$, and DC voltage DC link $\left(\mathrm{V}_{\mathrm{dc}}\right)$. Then, THD value of source voltage, source current, load voltage, and load current in each phase as well as average THD value (Avg THD) are obtained base on the curves. THD in each phase is determined in one cycle started at $t=0.35 \mathrm{~s}$. The results of average of source voltage, source current, load voltage, and load current of 3P3W system using UPQC-BES system supplied by three RE sources i.e. PV, wind, and PV-wind hybrid are presented in Table 2, 3, and 4. Next THD in each phase and average THD are showed in Table 5, 6 and 7.

Table 2 shows UPQC-BES system supplied PV connected 3P3W system using PI and FLC, disturbance scenarios 1 to 5 produce an average load voltage above $307 \mathrm{~V}$. While in scenario 6, FLC produces a higher average load voltage of $304.1 \mathrm{~V}$ than if using a PIof $286.7 \mathrm{~V}$. If reviewed from average source current with PI, the highest and lowest average source currents are generated by disturbance scenarios 2 and 4 of 28.15

Matlab/simulink simulation of unified power quality conditioner-battery energy storage... (Amirullah) 
A and 7,246 A. Whereas if using FLC the highest and lowest average source currents are achieved in scenario 2 and 6 of 28.84 A and 3.804 A. Table 3 shows UPQC-BES supplied by wind connected to 3P3W with PI and FLC, scenarios 1 to 5 is able to obtain a stable load voltage above $308 \mathrm{~V}$. The difference is that in scenario 6 , PI generates a load voltage of $274.8 \mathrm{~V}$, otherwise if using FLC, load voltage increases to $306.4 \mathrm{~V}$. If reviewed from source current using PI, the highest and lowest average source currents are resulted by scenarios 2 and 4 of 28.28 A and 7.417 A. Rather, if using FLC, the highest and lowest average source currents are achieved in scenario 2 and 6 of $28.82 \mathrm{~A}$ and 3,420 A. Table 4 shows UPQC-BES supplied PV-wind hybrid connected 3P3W using PI and FLC, scenarios 1 to 5 produce an average load voltage above $307 \mathrm{~V}$. While in scenario 6 , FLC generates an average load voltage $305.9 \mathrm{~V}$ higher than if using PI control of $283.9 \mathrm{~V}$. If reviewed from average source current with PI, the highest and lowest average source currents are resulted by scenarios 2 and 4 of 28.21 A and 6,773 A. Otherwise if using FLC the highest and lowest average source currents are achieved in scenario 2 and 6 of $28.82 \mathrm{~A}$ and $3.640 \mathrm{~A}$ respectively.

Table 2. Voltage and Current of 3P3W System Using UPQC-BES System Supplied by PV

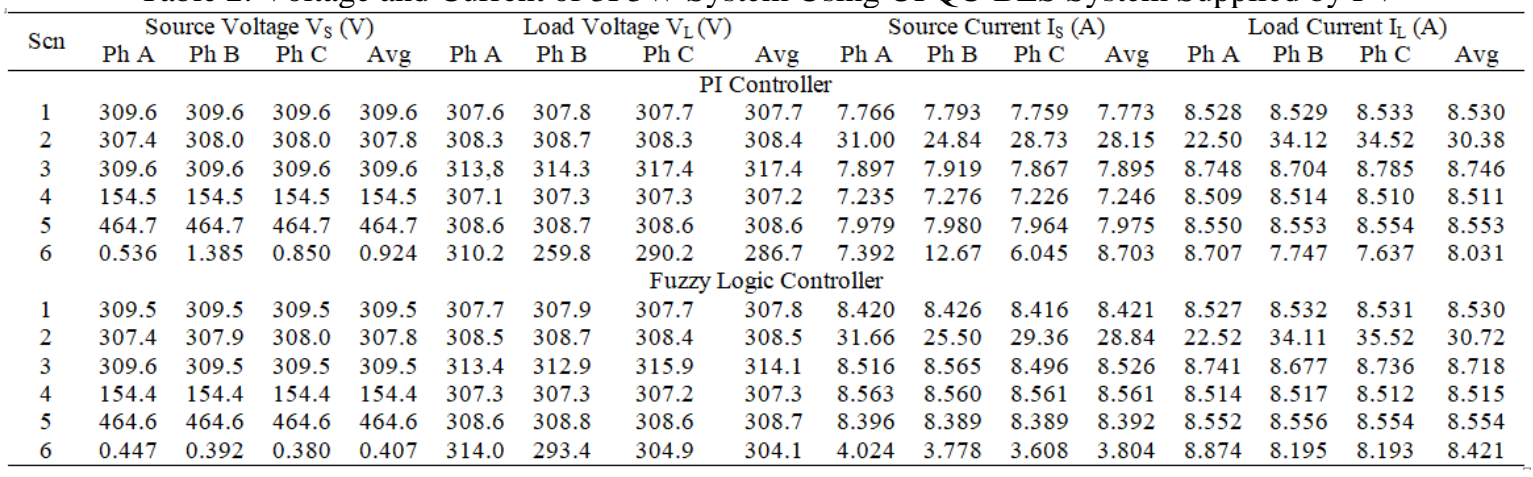

Table 3. Voltage and Current of 3P3W System Using UPQC-BES System Supplied by Wind

\begin{tabular}{|c|c|c|c|c|c|c|c|c|c|c|c|c|c|c|c|c|}
\hline \multirow{2}{*}{ Scn } & \multicolumn{4}{|c|}{ Source Voltage $\mathrm{V}_{\mathrm{S}}(\mathrm{V})$} & \multicolumn{4}{|c|}{ Load Voltage $\mathrm{V}_{\mathrm{L}}(\mathrm{V})$} & \multicolumn{4}{|c|}{ Source Current IS (A) } & \multicolumn{4}{|c|}{ Load Current $\mathrm{I}_{\mathrm{L}}(\mathrm{A})$} \\
\hline & $\mathrm{Ph} \mathrm{A}$ & $\mathrm{Ph} \mathrm{B}$ & $\mathrm{PhC}$ & Avg & $\mathrm{Ph} \mathrm{A}$ & $\mathrm{Ph} \mathrm{B}$ & $\mathrm{Ph} \mathrm{C}$ & Avg & $\mathrm{Ph} \mathrm{A}$ & $\mathrm{Ph} \mathrm{B}$ & $\mathrm{PhC}$ & Avg & $\mathrm{Ph} \mathrm{A}$ & $\mathrm{Ph} \mathrm{B}$ & $\mathrm{Ph} \mathrm{C}$ & Avg \\
\hline 1 & 309.5 & 309.6 & 309.6 & 309.6 & 308.6 & 308.6 & 308.2 & 308.5 & 7.863 & 7.875 & 7.840 & 7.869 & 8.554 & 8.553 & 8.546 & 8.551 \\
\hline 3 & 309.6 & 309.5 & 309.6 & 309.6 & 312.9 & 312.9 & 315.4 & 313.8 & 7.993 & 8.015 & 7.947 & 7.985 & 8.817 & 8.682 & 8.741 & 8.747 \\
\hline 4 & 154.5 & 154.5 & 154.5 & 154.5 & 308.0 & 308.1 & 307.8 & 307.9 & 7.428 & 7.455 & 7.368 & 7.417 & 8.527 & 8.535 & 8.532 & 8.531 \\
\hline 5 & 464.7 & 464.7 & 464.7 & 464.7 & 309.3 & 309.3 & 309.0 & 309.2 & 8.015 & 8.020 & 8.002 & 8.012 & 8.564 & 8.573 & 8.568 & 8.568 \\
\hline 6 & 1.256 & 1.022 & 0.592 & 0.957 & 234.0 & 316.4 & 274.0 & 274.8 & 11.27 & 9.866 & 7.028 & 9.388 & 5.958 & 8.697 & 8.204 & 7.619 \\
\hline \multicolumn{17}{|c|}{ Fuzzy Logic Controller } \\
\hline 1 & 309.5 & 309.5 & 309.5 & 309.5 & 308.5 & 308.6 & 308.3 & 308.5 & 8.418 & 8.410 & 8.414 & 8.414 & 8.545 & 8.552 & 8.549 & 8.549 \\
\hline 2 & 307.4 & 307.9 & 308.0 & 307.8 & 309.0 & 309.3 & 308.9 & 309.1 & 31.64 & 25.47 & 29.34 & 28.82 & 22.56 & 34.18 & 34.59 & 30.44 \\
\hline 3 & 309.5 & 309.5 & 309.5 & 309.5 & 313.2 & 313.7 & 314.1 & 313.7 & 8.519 & 8.531 & 8.531 & 8.527 & 8.713 & 8.714 & 8.718 & 8.715 \\
\hline 4 & 154.4 & 154.4 & 154.4 & 154.4 & 308.0 & 308.1 & 307.7 & 307.9 & 8.557 & 8.539 & 8.561 & 8.552 & 8.528 & 8.541 & 8.525 & 8.531 \\
\hline 5 & 464.6 & 464.7 & 464.7 & 464.7 & 309.2 & 309.3 & 309.2 & 309.2 & 8.391 & 8.385 & 8.388 & 8.388 & 8.565 & 8.570 & 8.567 & 8.567 \\
\hline 6 & 0.357 & 0.396 & 0.397 & 0.383 & 303.7 & 300.0 & 315.3 & 306.4 & 3.358 & 3.464 & 3.542 & 3.420 & 8.557 & 8.418 & 8.731 & 8.569 \\
\hline
\end{tabular}

Table 4. Voltage and Current of 3P3W System Using UPQC-BES System Supplied PV-Wind Hybrid

\begin{tabular}{|c|c|c|c|c|c|c|c|c|c|c|c|c|c|c|c|c|}
\hline \multirow{2}{*}{ Scn } & \multicolumn{4}{|c|}{ Source Voltage $\mathrm{V}_{\mathrm{S}}(\mathrm{V})$} & \multicolumn{4}{|c|}{ Load Voltage $\mathrm{V}_{\mathrm{L}}(\mathrm{V})$} & \multicolumn{4}{|c|}{ Source Current $\mathrm{I}_{\mathrm{S}}(\mathrm{A})$} & \multicolumn{4}{|c|}{ Load Current $\mathrm{I}_{\mathrm{L}}(\mathrm{A})$} \\
\hline & $\mathrm{Ph} \mathrm{A}$ & $\mathrm{Ph} \mathrm{B}$ & $\mathrm{PhC}$ & Avg & $\mathrm{Ph} \mathrm{A}$ & $\mathrm{Ph} \mathrm{B}$ & $\mathrm{Ph} \mathrm{C}$ & Avg & $\mathrm{Ph} \mathrm{A}$ & $\mathrm{Ph} \mathrm{B}$ & $\mathrm{Ph} \mathrm{C}$ & Avg & $\mathrm{Ph} \mathrm{A}$ & $\mathrm{Ph} \mathrm{B}$ & $\mathrm{PhC}$ & Avg \\
\hline 1 & 309.6 & 309.6 & 309.6 & 309.6 & 307.8 & 308.0 & 307.7 & 307.8 & 7.790 & 7.802 & 7.770 & 7.787 & 8.527 & 8.537 & 8.533 & 8.533 \\
\hline 3 & 309.6 & 309.5 & 309.6 & 309.6 & 314.0 & 315.5 & 316.9 & 315.5 & 7.942 & 7.939 & 7.918 & 7.933 & 8.739 & 8.750 & 8.783 & 8.757 \\
\hline 4 & 154.5 & 154.5 & 154.5 & 154.5 & 307.3 & 307.4 & 307.2 & 307.3 & 7.289 & 7.309 & 7.251 & 7.283 & 8.513 & 8.516 & 8.515 & 8.515 \\
\hline 5 & 464.7 & 464.7 & 464.7 & 464.7 & 308.7 & 308.9 & 308.7 & 308.8 & 7.985 & 7.985 & 7.975 & 7.982 & 8.552 & 8.558 & 8.558 & 8.556 \\
\hline 1 & 309.5 & 309.5 & 309.5 & 309.5 & 307.8 & 308.0 & 307.7 & 307.8 & 8.419 & 8.418 & 8.409 & 8.413 & 8.529 & 8.539 & 8.533 & 8.534 \\
\hline 2 & 307.4 & 307.9 & 308.0 & 307.8 & 308.7 & 308.7 & 308.9 & 308.8 & 31.66 & 25.47 & 29.32 & 28.82 & 22.54 & 34.13 & 34.56 & 30.41 \\
\hline 3 & 309.5 & 309.5 & 309.5 & 309.5 & 314.4 & 315.5 & 316.6 & 315.5 & 8.581 & 8.593 & 8.568 & 8.581 & 8.761 & 8.722 & 8.761 & 8.748 \\
\hline 4 & 154.4 & 154.4 & 154.4 & 154.4 & 307.3 & 307.5 & 307.3 & 307.4 & 8.566 & 8.572 & 8.563 & 8.567 & 8.511 & 8.520 & 8.519 & 8.517 \\
\hline 5 & 464.6 & 464.6 & 464.6 & 464.6 & 308.8 & 308.8 & 308.7 & 308.8 & 8.391 & 8.394 & 8.396 & 8.394 & 22.33 & 22.35 & 22.36 & 22.35 \\
\hline 6 & 0.412 & 0.403 & 0.402 & 0.418 & 311.6 & 295.7 & 310.4 & 305.9 & 3.774 & 3.544 & 3.593 & 3.640 & 8.855 & 8.321 & 8.288 & 8.488 \\
\hline
\end{tabular}


Table 5. Harmonics of 3P3W System Using UPQC-BES System Supplied by PV

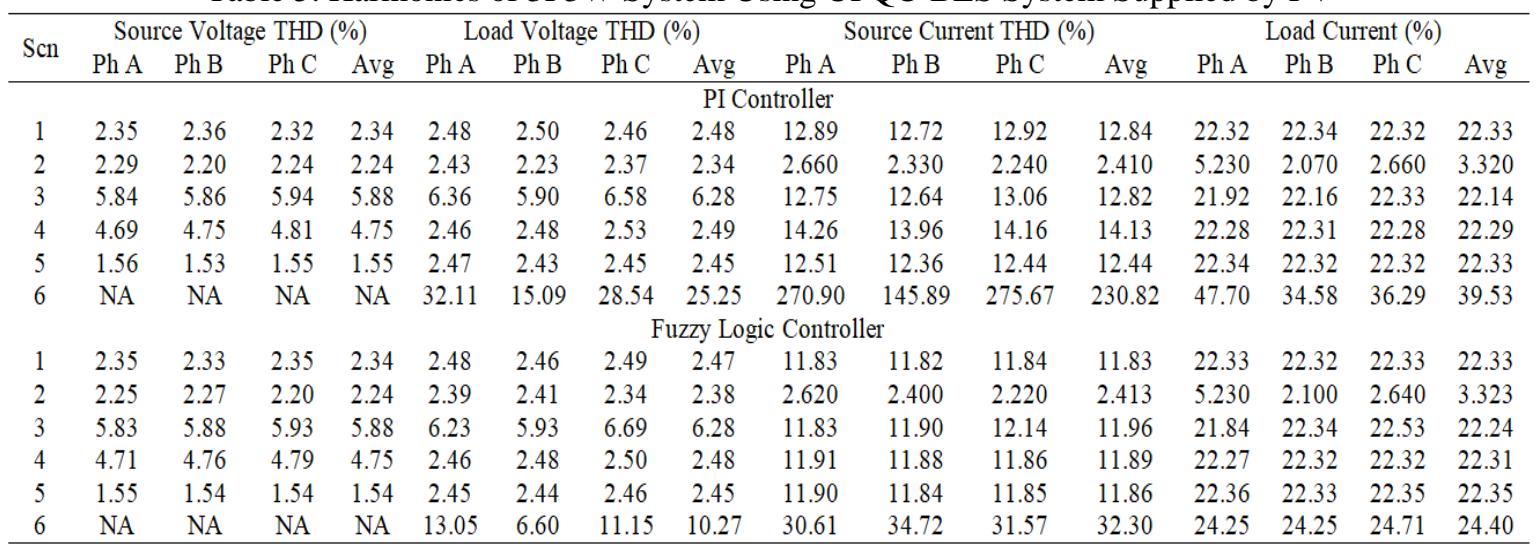

Table 6. Harmonics of 3P3W System Using UPQC-BES System Supplied by Wind

\begin{tabular}{|c|c|c|c|c|c|c|c|c|c|c|c|c|c|c|c|c|}
\hline \multirow{2}{*}{ Scn } & \multicolumn{4}{|c|}{ Source Voltage THD (\%) } & \multicolumn{4}{|c|}{ Load Voltage THD (\%) } & \multicolumn{4}{|c|}{ Source Current THD (\%) } & \multicolumn{4}{|c|}{ Load Current (\%) } \\
\hline & $\mathrm{Ph} \mathrm{A}$ & $\mathrm{Ph} \mathrm{B}$ & $\mathrm{PhC}$ & Avg & $\mathrm{Ph} \mathrm{A}$ & $\mathrm{Ph} \mathrm{B}$ & $\mathrm{PhC}$ & Avg & $\mathrm{Ph} \mathrm{A}$ & $\mathrm{Ph} \mathrm{B}$ & $\mathrm{PhC}$ & Avg & $\mathrm{Ph} \mathrm{A}$ & $\mathrm{Ph} \mathrm{B}$ & $\mathrm{PhC}$ & Avg \\
\hline \multicolumn{17}{|c|}{ PI Controller } \\
\hline 1 & 1.88 & 1.87 & 1.94 & 1.89 & 1.99 & 1.97 & 2.05 & 2.00 & 12.63 & 12.37 & 12.70 & 12.57 & 12.30 & 12.30 & 12.34 & 12.31 \\
\hline 3 & 5.67 & 5.71 & 5.77 & 5.72 & 6.00 & 6.83 & 6.02 & 6.28 & 12.48 & 12.26 & 12.66 & 12.47 & 22.01 & 22.12 & 22.08 & 22.07 \\
\hline 4 & 3.76 & 3.86 & 3.86 & 1.83 & 1.97 & 2.02 & 2.03 & 2.01 & 13.59 & 13.17 & 13.51 & 13.42 & 22.29 & 22.31 & 22.30 & 22.30 \\
\hline 5 & 1.26 & 1.24 & 1.29 & 1.26 & 1.99 & 1.97 & 2.05 & 2.00 & 12.31 & 12.20 & 12.31 & 12.27 & 22.36 & 22.33 & 22.37 & 22.35 \\
\hline 1 & 1.89 & 1.88 & 1.93 & 1.90 & 1.99 & 1.98 & 2.04 & 2.00 & 11.71 & 11.72 & 11.77 & 11.73 & 22.34 & 22.31 & 22.32 & 22.32 \\
\hline 2 & 1.85 & 1.79 & 1.78 & 1.81 & 1.95 & 1.87 & 1.88 & 1.90 & 2.43 & 2.11 & 2.12 & 2.220 & 5.240 & 2.070 & 2.700 & 3.240 \\
\hline 3 & 5.67 & 5.71 & 5.78 & 5.72 & 5.99 & 6.39 & 6.13 & 6.17 & 11.72 & 11.62 & 11.90 & 11.75 & 22.08 & 21.94 & 22.47 & 22.16 \\
\hline 4 & 3.79 & 3.81 & 3.86 & 3.82 & 1.97 & 1.99 & 2.03 & 1.99 & 11.72 & 11.69 & 11.74 & 11.72 & 22.28 & 22.30 & 22.35 & 22.31 \\
\hline 5 & 1.27 & 1.24 & 1.28 & 1.26 & 2.00 & 1.96 & 2.04 & 2.00 & 11.66 & 11.76 & 11.76 & 11.73 & 22.31 & 22.33 & 22.35 & 22.33 \\
\hline
\end{tabular}

Table 7. Harmonics of 3P3W System Using UPQC-BES System Supplied by PV-Wind Hybrid

\begin{tabular}{|c|c|c|c|c|c|c|c|c|c|c|c|c|c|c|c|c|}
\hline \multirow{2}{*}{ Scn } & \multicolumn{4}{|c|}{ Source Voltage THD (\%) } & \multicolumn{4}{|c|}{ Load Voltage THD (\%) } & \multicolumn{4}{|c|}{ Source Current THD (\%) } & \multicolumn{4}{|c|}{ Load Current (\%) } \\
\hline & $\mathrm{Ph} \mathrm{A}$ & $\mathrm{Ph} \mathrm{B}$ & $\mathrm{PhC}$ & Avg & $\mathrm{Ph} \mathrm{A}$ & $\mathrm{PhB}$ & $\mathrm{PhC}$ & Avg & $\mathrm{Ph} \mathrm{A}$ & $\mathrm{Ph} \mathrm{B}$ & $\mathrm{PhC}$ & Avg & $\mathrm{Ph} \mathrm{A}$ & $\mathrm{Ph} \mathrm{B}$ & $\mathrm{PhC}$ & Avg \\
\hline 1 & 2.25 & 2.19 & 2.29 & 2.24 & 2.37 & 2.31 & 2.42 & 3.37 & 12.85 & 12.62 & 12.74 & 12.74 & 22.33 & 22.31 & 22.34 & 22.33 \\
\hline 3 & 5.81 & 5.82 & 5.89 & 5.84 & 6.12 & 5.88 & 6.75 & 6.25 & 12.71 & 12.63 & 12.98 & 12.77 & 22.05 & 22.13 & 22.54 & 22.24 \\
\hline 4 & 4.53 & 4.48 & 4.51 & 4.51 & 2.37 & 2.35 & 2.37 & 2.36 & 14.16 & 13.50 & 13.99 & 13.88 & 22.27 & 22.30 & 22.28 & 22.28 \\
\hline 5 & 1.49 & 1.46 & 1.51 & 1.49 & 2.37 & 2.31 & 2.40 & 2.36 & 12.43 & 12.29 & 12.41 & 12.38 & 22.34 & 22.32 & 22.33 & 22.33 \\
\hline 1 & 2.25 & 2.23 & 2.25 & 2.24 & 2.37 & 2.35 & 2.39 & 2.37 & 11.85 & 11.74 & 11.84 & 11.81 & 22.32 & 22.31 & 22.33 & 22.32 \\
\hline 2 & 2.23 & 2.15 & 2.05 & 2.14 & 2.37 & 2.26 & 2.17 & 2.26 & 2.520 & 2.410 & 2.140 & 2.446 & 5.230 & 2.070 & 2.690 & 3.330 \\
\hline 3 & 5.80 & 5.83 & 5.90 & 5.84 & 6.57 & 5.26 & 7.06 & 6.29 & 11.83 & 11.78 & 12.24 & 11.95 & 22.15 & 22.23 & 22.95 & 22.44 \\
\hline 4 & 4.53 & 4.52 & 4.54 & 4.86 & 2.36 & 2.35 & 2.35 & 2.35 & 11.79 & 11.74 & 11.84 & 11.79 & 22.29 & 22.30 & 22.29 & 22.29 \\
\hline 5 & 1.48 & 1.46 & 1.51 & 1.48 & 2.35 & 2.32 & 2.40 & 2.35 & 11.78 & 11.81 & 11.81 & 11.80 & 22.33 & 22.35 & 22.36 & 22.35 \\
\hline
\end{tabular}

Table 5 shows that average THD of load voltage $\left(\mathrm{V}_{\mathrm{L}}\right)$ of UPQC-BES system supplied by PV in 3P3W system for scenarios 1 to 5 using PI control is within limits in IEEE 519. The highest and lowest average THD load voltages are achieved under scenario 6 and 2 as $25.25 \%$ and $2.34 \%$ respectively. PI controller is also able to mitigate average THD source voltage in scenario 6 from not accessible (NA) to $25.25 \%$ on the load side. The highest and lowest average THD of source current are achieved in scenario 6 and 2 as $230.82 \%$ and $2.41 \%$. Table 5 also indicates that average THD of load voltage of UPQC system supplied by PV with BES using FLC in scenarios 1 to 5, has fulfilled limits in IEEE 519. The highest and lowest average THD of load voltage are achieved under scenario 6 and 2 of $10.27 \%$ and $2.38 \%$. The use of FLC method is also able to reduce average THD on source voltage in scenario 6 from NA to $10.27 \%$ on load side. The highest and lowest average THD of source current are achieved in scenario 6 and 2 of $32.30 \%$ and $2.413 \%$.

Table 6 shows that average THD of load voltage of UPQC-BES system supplied by wind in 3P3W system for interference scenarios 1 to 5 using PI is within limits prescribed in IEEE 519. The highest and lowest 
average THD load voltages is achieved under scenario 6 and scenario 2 as $28.14 \%$ and $1.90 \%$ respectively. PI controller is also able to reduce average THD source voltage in scenario 6 from NA to $28.14 \%$ on the load side. The highest and lowest average THD of source current are achieved in scenario 6 and 2 as $186.95 \%$ and $2.24 \%$ respectively. Table 6 also shows that average THD of load voltage of UPQC-BES supplied by wind using FLC in scenarios 1 to 5, has fulfilled limits prescribed in IEEE 519. The highest and lowest average THD of load voltage are achieved under scenario 6 and 4 of $8.33 \%$ and $1.90 \%$. FLC method is also able to reduce average THD on source voltage in scenario 6 from NA to $7.33 \%$ on load side. The highest and lowest average THD source current are achieved in scenario 6 and 2 of $27.33 \%$ and $2.22 \%$.

Table 7 shows that average THD of load voltage $\left(\mathrm{V}_{\mathrm{L}}\right)$ of UPQC-BES system supplied by PV-wind hybrid in 3P3W system for scenarios 1 to 5 using PI is within limits in IEEE 519. The highest and lowest average THD load voltages are achieved under scenario 6 and 2 as $27.8 \%$ and $2.22 \%$ respectively. PI is also able to mitigate average THD source voltage in scenario 6 from NA to $27.8 \%$ on load side. The highest and lowest average THD of source current are achieved in scenario 6and 2 as $302.45 \%$ and $2.407 \%$ respectively. Table 7 also indicates that average THD of load voltage of UPQC-BES system supplied by PV-wind hybrid using FLC for scenarios 1 to 5, has fulfilled limits in IEEE 519. The highest and lowest average THD of load voltage are achieved under scenario 6 and 2 of $8.48 \%$ and $2.26 \%$. FLC method is also able to reduce average THD on source voltage in scenario 6 from NA to $8.48 \%$ on load side. The highest and lowest average THD of source current are achieved in scenario 6and 2 of $28.53 \%$ and $2.446 \%$. Overall for UPQC-BES systemsystem supplied by three RE sources in scenarios 1 to 5 using PI and FLC is able to improve average THD of source current better on average THD of load current. Figure 9 presents UPQC-BES system performance supplied by three RE sources using FLC in scenario 6.

Figure 9 a(i) shows that in scenario 6, UPQC-BES system supplied by PV at $t=0.2 \mathrm{~s}$ to $\mathrm{t}=0.5 \mathrm{~s}$, average source voltage $\left(\mathrm{V}_{\mathrm{S}}\right)$ falls as $100 \%$ to $0.4062 \mathrm{~V}$. During the disturbance, PV is able to generate power to UPQC DC link and injecting full average compensation voltage $\left(V_{C}\right)$ in Figure 9 a(iii) through injection transformer on series active filter so that average load voltage $\left(\mathrm{V}_{\mathrm{L}}\right)$ in Figure 9 a(ii) remains stable at 304.1 V. As long as fault period, although nominal of average source current ( $\left.\mathrm{I}_{\mathrm{S}}\right)$ in Figure 9 a(iv) drops to 3.804 A, combination of PV and BES is able to generate power, store excess energy of PV, and inject current into load through shunt active filter so that average load current $\left(\mathrm{I}_{\mathrm{L}}\right)$ in Figure 9 a(v) remains as 8.421 A. Figure $9 \mathrm{~b}(\mathrm{i})$ presents on UPQC-BES supplied by wind at $\mathrm{t}=0.2 \mathrm{~s}$ to $\mathrm{t}=0.5 \mathrm{~s}$ average source voltage $\left(\mathrm{V}_{\mathrm{S}}\right)$ drops $100 \%$ to $0.3828 \mathrm{~V}$. During the disturbance, wind is able to generate power to UPQC DC link and injecting full average compensation voltage $\left(\mathrm{V}_{\mathrm{C}}\right)$ in Figure $9 \mathrm{~b}$ (iii) through injection transformer on series active filter so that average load voltage $\left(\mathrm{V}_{\mathrm{L}}\right)$ in Figure $9 \mathrm{~b}$ (ii) remains stable at $306.4 \mathrm{~V}$. During fault period, although nominal of average source current $\left(\mathrm{I}_{\mathrm{S}}\right)$ falls to $3.420 \mathrm{~A}$, combination of wind and BES is able to generate power, store excess energy of wind, and inject current into load through shunt active filter so that average load current $\left(\mathrm{I}_{\mathrm{L}}\right)$ in Figure $9 \mathrm{~b}(\mathrm{v})$ remains as 8.569 A. Figure $9 \mathrm{c}(\mathrm{i})$ indicates on UPQC-BES supplied by PV-Wind Hybrid at $\mathrm{t}=0.2 \mathrm{~s}$ to $\mathrm{t}=0.5 \mathrm{~s}$ average source voltage $\left(\mathrm{V}_{\mathrm{S}}\right)$ drops $100 \%$ to $0.4175 \mathrm{~V}$. During the disturbance, PV-wind hybrid is able to generate power to UPQC DC link and injecting full average compensation voltage $\left(\mathrm{V}_{\mathrm{C}}\right)$ in Figure $9 \mathrm{c}$ (iii) through injection transformer on series active filter so that average load voltage $\left(\mathrm{V}_{\mathrm{L}}\right)$ in Figure $9 \mathrm{~b}$ (ii) remains stable at 305.9 V. As long as disturbance period, although nominal of average source current $\left(\mathrm{I}_{\mathrm{S}}\right)$ falls to $3.640 \mathrm{~A}$, combination of PV-wind hybrid and BES is able to generate power, store excess energy of wind, and inject current into load through shunt active filter so that average load current $\left(\mathrm{I}_{\mathrm{L}}\right)$ in Figure $9 \mathrm{c}(\mathrm{v})$ remains as 8.488 A.

Figure 10 shows spectra of load voltage harmonics on phase A of UPQC-BES system supplied by three RE sources using FLC in scenario 6. Figure 11 shows performance of average THD of load voltage and source current on UPQC-BES system supplied by three RE sources. Figure 11(a) shows that in scenario 1 to 5, the implementation of FLC on UPQC-BES system supplied by three RE sources is able to obtain average THD of load voltage slightly better than PI controller and both method have already met the limit in IEEE 519. Further under scenario 6, FLC applied on UPQC-BES system supplied by three RE sources gives significantly better result of average THD of load voltage than PI controller. In six disturbance scenarios, both PI controller and FLC applied on UPQC-BES system supplied by three RE sources, PV is able to obtain the highest average THD of load voltages. Figure 11(b) shows that in disturbance scenario 1 to 5, implementation of FLC on UPQC-BES system supplied by three RE sources is able to obtain average THD of source current slightly better than PI controller. Furthermore under scenario 6, FLC applied on UPQC-BES system supplied by three RE sources gives significantly better result of average THD of source current than PI controller. Both PI controller and FLC on UPQC-BES system supplied by three RE sources in six disturbance scenarios, $\mathrm{PV}$ is able to obtain the highest average THD of source current. 


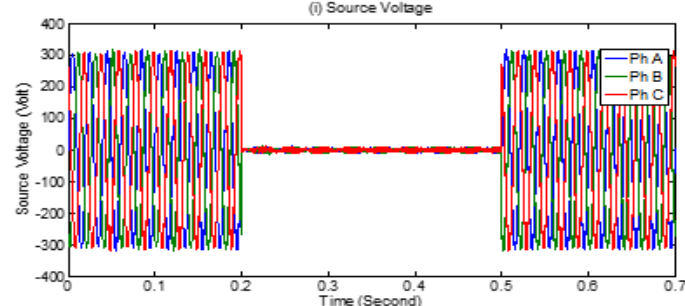

a(i). Source Voltage for UPQC-BES+PV

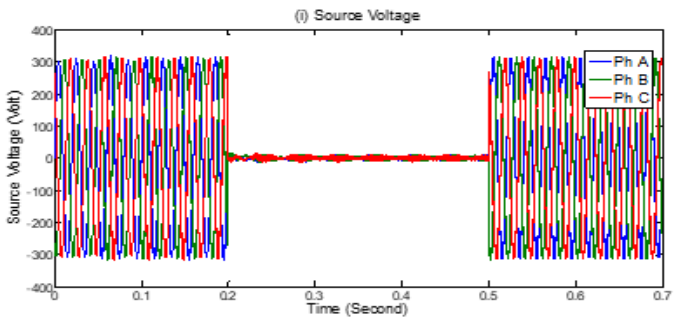

b(i). Source Voltage for UPQC-BES+Wind

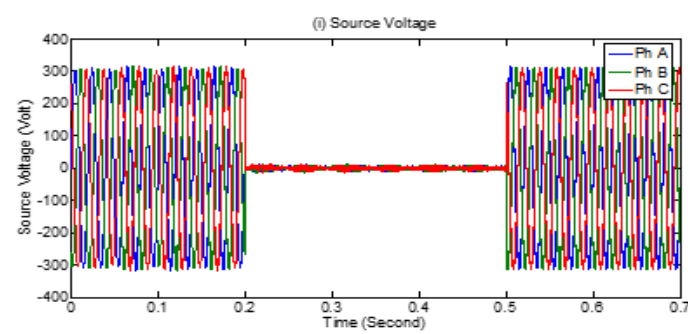

c(i). Source Voltage for UPQC-BES+PV-Wind Hybrid

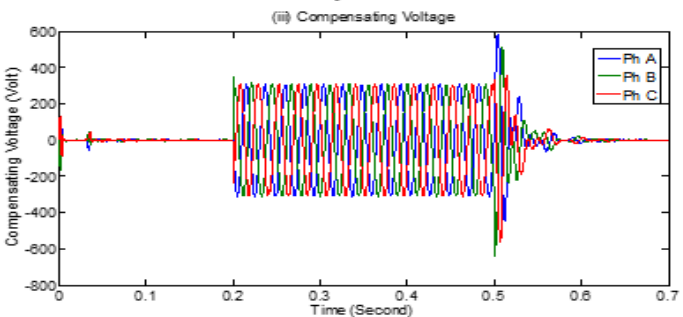

a(iii). Compensating Voltage for UPQC-BES+PV

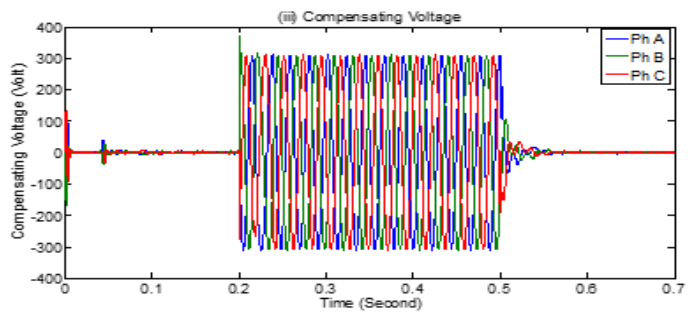

b(iii). Compensating Voltage for UPQC-BES+Wind

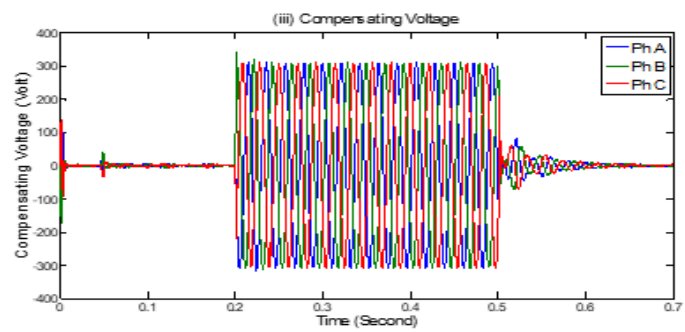

c(iii). Compensating Voltage for UPQC-BES+PVWind Hybrid

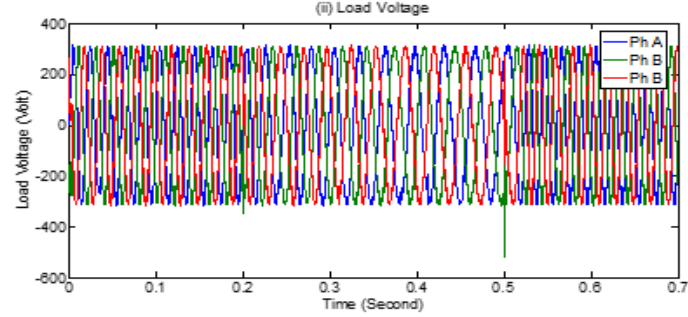

a(ii). Load Voltage for UPQC-BES+PV

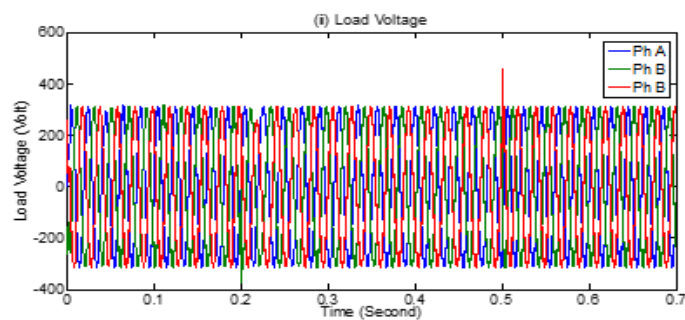

b(ii). Load Voltage for UPQC-BES+Wind

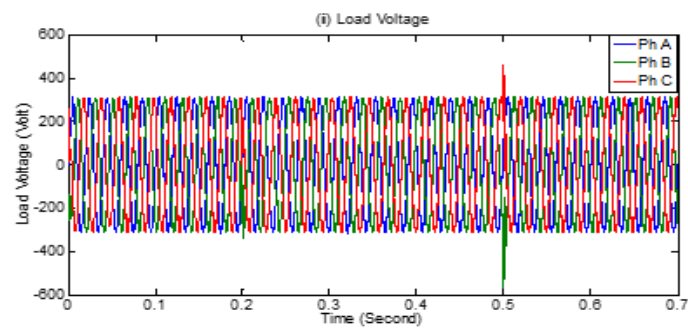

c(ii). Load Voltage for UPQC-BES+PV-Wind Hybrid

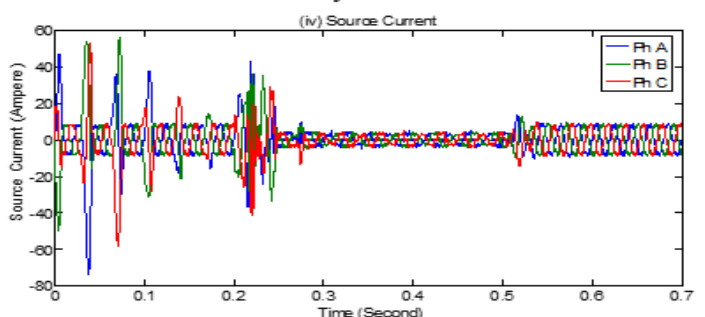

a(iv). Source Current for UPQC-BES+PV

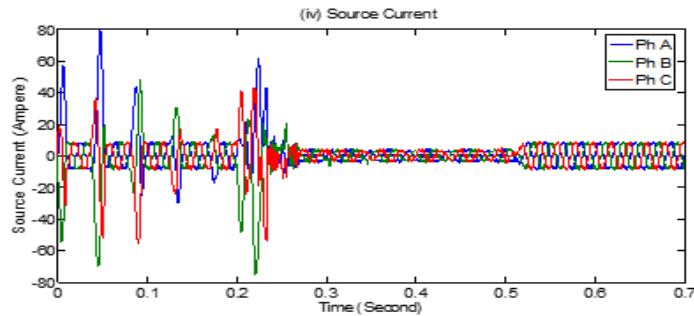

b(iv). Source Current for UPQC-BES+Wind

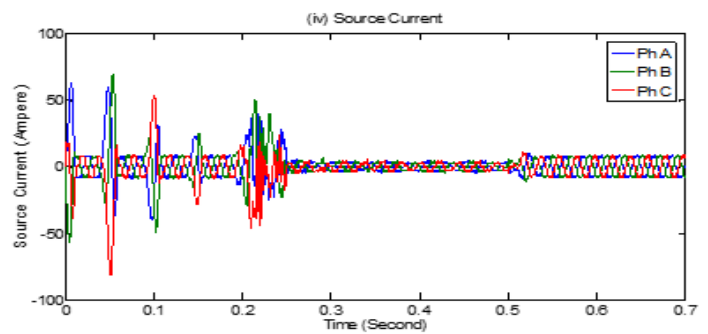

c(iv). Source Current for UPQC-BES+PV-Wind Hybrid

Figure 9. UPQC-BES system performance using FLC in scenario 6 (Inter-NL):

(a) UPQC-BES + PV; (b) UPQC-BES + Wind; (c) UPQC-BES + PV-Wind Hybrid (continue)

Matlab/simulink simulation of unified power quality conditioner-battery energy storage... (Amirullah) 

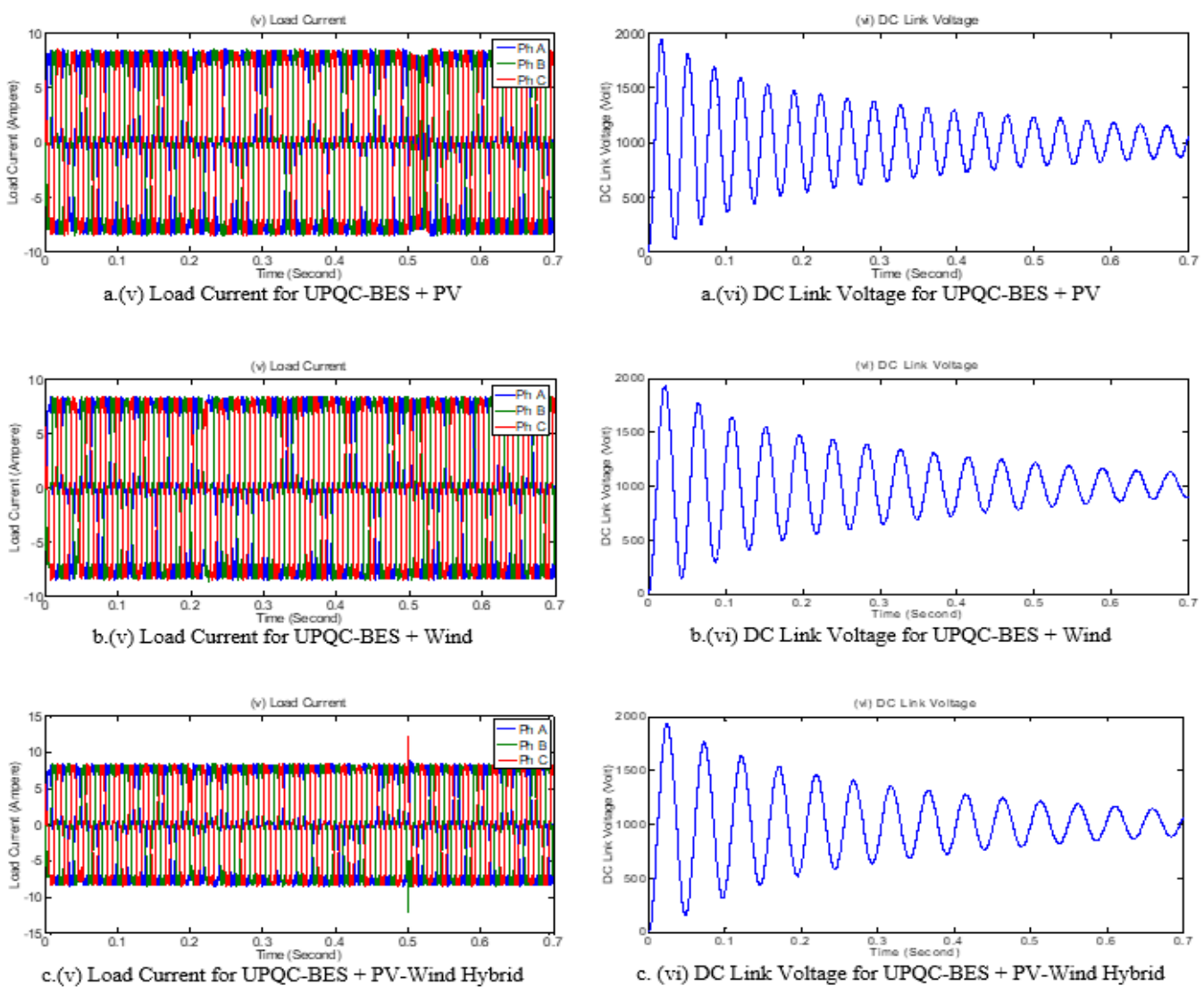

c. (vi) DC Link Voltage for UPQC-BES + PV-Wind Hybrid

Figure 9. UPQC-BES system performance using FLC in scenario 6 (Inter-NL):

(a) UPQC-BES + PV; (b) UPQC-BES + Wind; (c) UPQC-BES + PV-Wind Hybrid

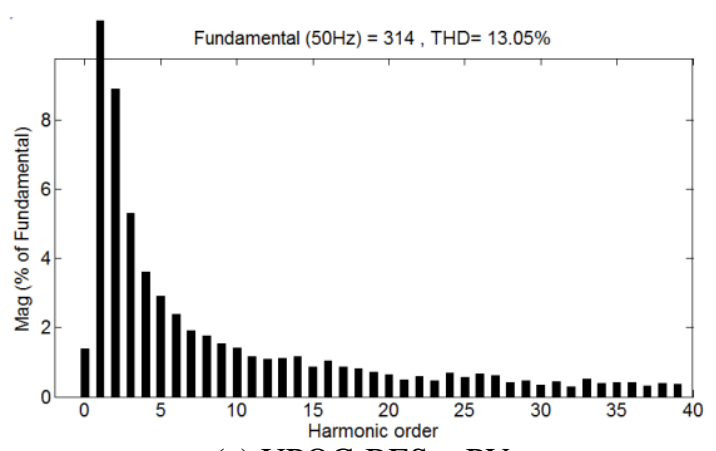

(a) UPQC-BES + PV

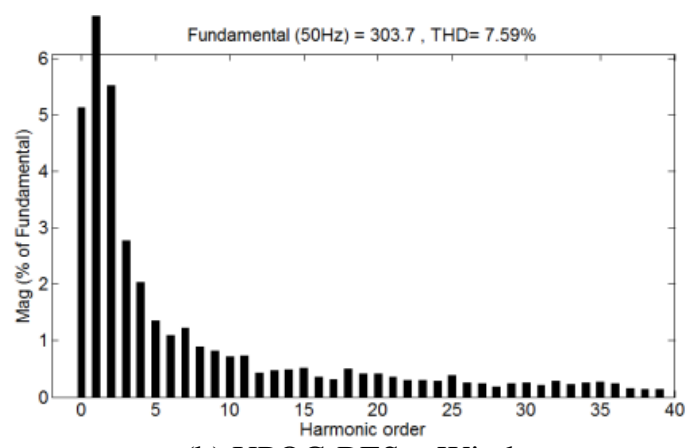

(b) UPQC-BES + Wind

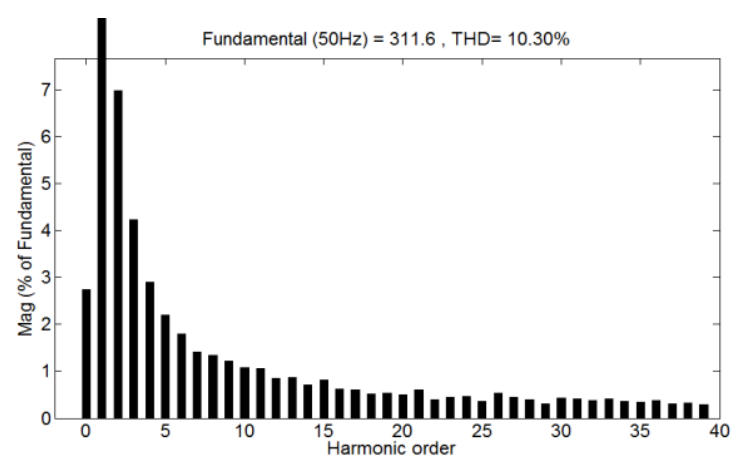

(c) UPQC-BES + PV-Wind Hybrid

Figure 10. Spectra of load voltage harmonics on phase A of UPQC-BES using FLC in scenario 6 (Inter-NL) 


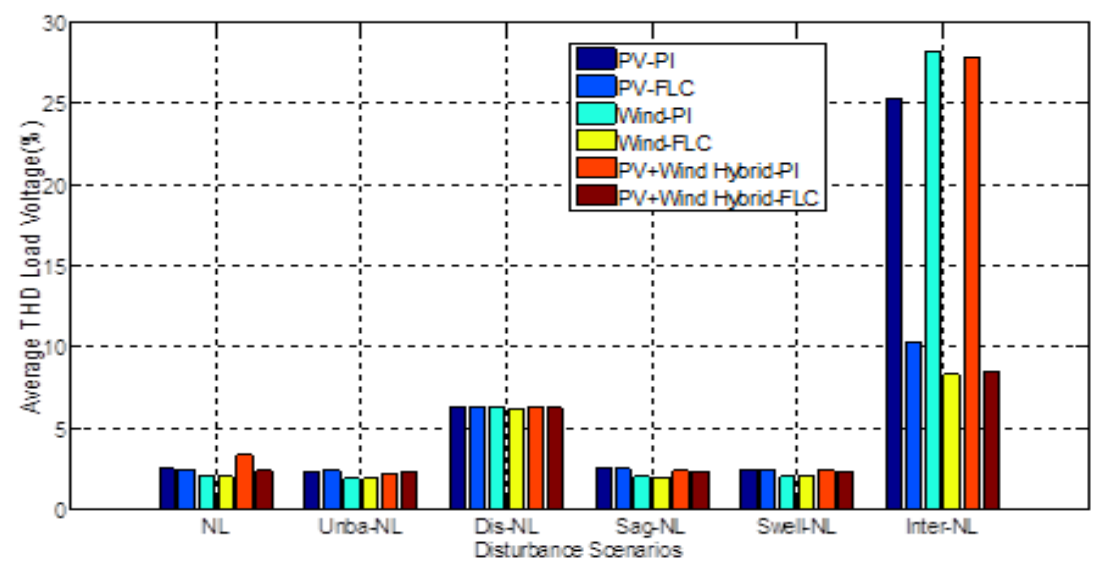

(a) Average load voltage harmonics

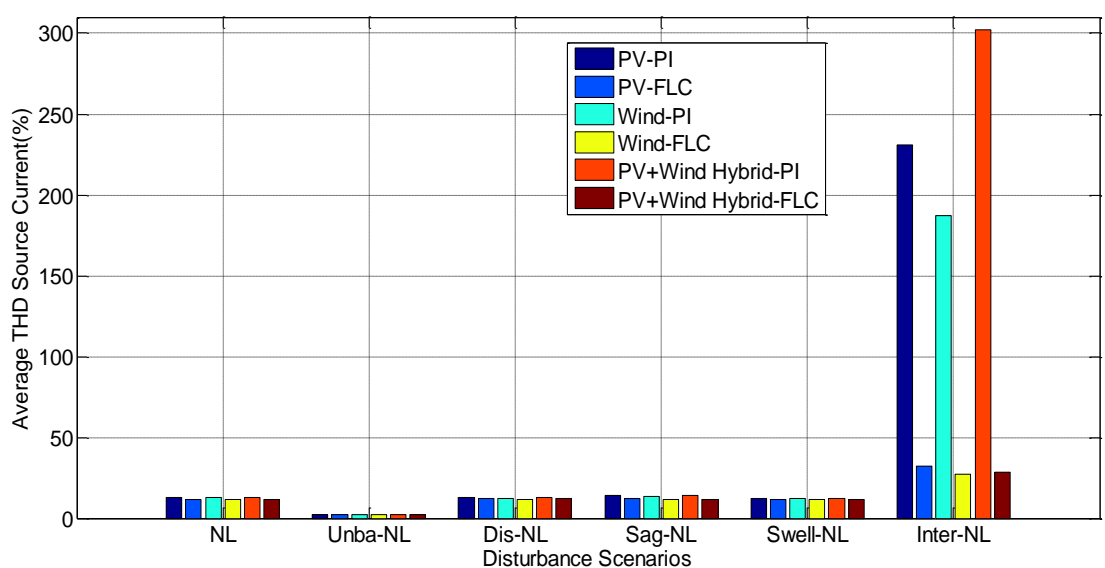

(b) Average source current harmonics

Figure 11. Performance of UPQC-BES supplied by three RE sources using PI and FLC

\section{CONCLUSION}

Comparative performance analysis of UPQC-BES system supplied by three RE sources i.e. PV, wind, and PV-wind hybrid respectively using PI controller and FLC have been discussed. In disturbance scenario 1 to 5, implementation of FLC on UPQC-BES system supplied by three RE sources is able to obtain average THD of load voltage slightly better than PI and both methods have already met the limit in IEEE 519. Under scenario 6, FLC applied on UPQC-BES system supplied by three RE sources gives significantly better result average THD of load voltage than PI. In six disturbance scenarios, both PI and FLC applied on UPQCBES system supplied by three RE sources, PV is able to obtain the highest average THD of load voltage. In interference scenario 1 to 5, FLC method on UPQC-BES system supplied by three RE sources is able to obtain average THD of source current slightly better than PI. Furthermore under scenario 6, FLC applied on UPQC-BES system supplied by three RE sources gives significantly better result of average THD of source current than PI. Both PI and FLC on UPQC-BES system supplied by three RE sources in six scenarios, $\mathrm{PV}$ is able to obtain the highest average THD of source current.

\section{ACKNOWLEDGEMENTS}

The authors would like to acknowledge to Ministry of Research, Technology, and Higher Education, Republic of Indonesia, for financial support by BPP-DN Scholarships to pursue Doctoral Program in Department of Electrical Engineering, Faculty of Electrical Technology, ITS Surabaya. 


\section{REFERENCES}

[1] B. Han, et.al, "Combined Operation of Unified Power Quality Conditioner With Distributed Generation," IEEE Transactions on Power Delivery, Vol. 21, No. 1, pp. 330-338, Januari 2006.

[2] Vinod Khadkikar, "Enhanching Electric Power Quality UPQC: A. Comprehensive Overview," IEEE Transactions on Power Electronics, Vol. 27, No. 5, pp. 2284-2297, May 2012.

[3] Shafiuzzaman K. Khadem, et.al.,"Integration of UPQC for Power Quality Improvement in Distribution Genertation Network," ISGT Europe 2011, Manchester, United Kingdom, December 2011.

[4] NorshafinashSaudinet.al,"SStudy on The Effect of Distributed Generation towards Unified Power Quality Conditioner Performance in Mitigating Voltage Sags,"IEEE International Conference on Power and Energy (PECon), Kota Kinibalu, Sabah, Malaysia, pp. 695-7002-5, December 2012.

[5] S. N. Gohil, et.al.,"Three Phase Unified Power Quality Conditioner (UPQC) for Power Quality Improvement by using UVTG technique," 2013 International Conference on Renewable Energy and Sustainable Energy (ICRESE), Coimbatore,pp 151 - 156,5-6 Dec. 2013.

[6] Yahia Bouzelata, et.al.,"Design and Simulation of Unified Power Quality Conditioner Fed by Solar Energy," International Journal of Hydrogen Energy Vol. 40, Elsevier Ltd, pp. 15267-15277, 2015.

[7] K.Ramalingeswara Rao et.al., "Improvement of Power Quality using Fuzzy Logic Controller In Grid Connected Photovoltaic Cell Using UPQC,"International Journal of Power Electronics and Drive System (IJPEDS) Vol. 5, No. 1, pp. 101 111 ISSN: 2088-8694, July 2014.

[8] Amirullah, et.al.,"Multi Units of Single Phase Distributed Generation Combined With Battery Energy Storage for Phase Balancing in Distribution Network," Vol. 78: 10-4, eISSN 2180-3722, Universiti Teknologi Malaysia (UTM) Publisher, pp. 27-33, 2016.

[9] K.S. Srikanth, et.al.,,"Improvement of Power Quality for Microgrid Using Fuzzy Based UPQC Controller,"International Conference on Electrical, Electronics, Signals, Communication and Optimization (EESCO), Visakhapatnam, 24-25, pp. 1-6, Jan 2015.

[10] H. Toodeji, et.al., ,"Power Management and Performance Improvement in Integrated System of Variable Speed Wind Turbin and UPQC,"International Conference onClean Electrical Power, 9-11, pp. 609-614, June 2009.

[11] M. Hosseipour, et.al., "Design and Simulation of UPQC to Improve Power Quality and Transfer Wind Energy to Grid", Journal of Applied Sciences 8 (21), pp. 3770-3782,2008.

[12] R. Bhavani, et.al, ,"Fuzzy Connected UPQC for Power Quality Enhancement in DFIG based Grid Connected Wind Power System", International Conference on Circuit, Power and Computing Technologies (ICCPCT), 19-20, Nagercoil, pp. 1-7, March 2015.

[13] S. Rajesh Rajan, "Power Quality Improvement in Grid Connected Wind Energi System Using UPQC", International Journal of Research in Engineering and Technology (IJRET), Vol. 1, Issue 1, pp. 13-19, June 2013.

[14] Ali Reza Reisi, et.al, "Combined Photovoltaic and Unified Power Quality Controller to Improve Power Quality", Solar Energy 88, pp.154-162, 2013.

[15] Mallikarjuna and K. Amaresh, "Implementation of UPQC in Micro Grid Applications with Renewable Energy Resources", International Journal of Scientific Engineering and Technology Research, Vol. 4, Issue.36, pp. 77347739, September-2015.

[16] Yash Pal, et.al.,"A Comparative Analysis of Different Magnetic Support Three Phase Four Wire Unified Power Quality Conditioners - A Simulation Study”, Electrical Power and Energy System 47,pp. 437-447, 2013.

[17] Swapnil Y. Kamble and Madhukar M. Waware, "Unified Power Quality Conditioner for Power Quality Improvement", International Multi Conference on Automation, Computing, Communication, Control and Compressed Sensing (iMac4s), Kottayam, India, 22-23 March 2013, pp. 432-437, 2013.

[18] MihirHembram and Ayan Kumar Tudu, "Mitigation of Power Quality Problems Using Unified PowerQuality Conditioner (UPQC)", Proceedings of the 2015 Third International Conference on Computer, Communication, Control and Information Technology (C3IT), (2015), Hooghly, India, 7-8, pp.1-5, February 2015.

[19] Amirullah and AgusKiswantono, "Power Quality Enhancement of Integration Photovoltaic Generator to Grid under Variable Solar Irradiance Level using MPPT-Fuzzy," International Journal of Electrical and Computer Engineering (IJECE),IAES Publisher, Vol. 6, No. 6, pp.2629-2642, December 2016.

\section{APPENDIX}

Three phase grid: RMS voltage 380 volt $(\mathrm{L}-\mathrm{L}), 50 \mathrm{~Hz}$, line impedance: $\mathrm{R}_{\mathrm{s}}=0.1 \mathrm{Ohm} \mathrm{L}_{\mathrm{s}}=15 \mathrm{mH}$; series and shunt active filter: series inductance $\mathrm{L}_{\mathrm{se}}=0.015 \mathrm{mH}$; shunt inductance $\mathrm{L}_{\mathrm{sh}}=15 \mathrm{mH}$; injection transformers: rating $10 \mathrm{kVA}, 50 \mathrm{~Hz}$, turn ratio $\left(\mathrm{N}_{1} / \mathrm{N}_{2}\right)=1: 1$; non linear load: resistance $\mathrm{R}_{\mathrm{L}}=60 \mathrm{ohm}$, inductance $\mathrm{L}_{\mathrm{L}}=0.15 \mathrm{mH}$, load impedance $R_{c}=0.4 \mathrm{ohm}$ and $\mathrm{L}_{c}=15 \mathrm{mH}$; unbalance load: resistance $\mathrm{R}_{1}=24 \mathrm{ohm}, \mathrm{R}_{2}=12 \mathrm{ohm}$, and $\mathrm{R}_{3}=6$ ohm, capacitance $\mathrm{C}_{1}, \mathrm{C}_{2}, \mathrm{C}_{3}=2200 \mu \mathrm{F}$; DC-link: voltage $\mathrm{V}_{\mathrm{DC}}=650$ volt and capacitance $\mathrm{C}_{\mathrm{DC}}=3000 \mu \mathrm{F}$; battery energe storage: type $=$ nickel metal hybrid, $\mathrm{DC}$ voltage $=650$ volt, rated capacity $=200 \mathrm{Ah}$, initial $\mathrm{SOC}=100 \%$, inductance $\mathrm{L}_{1}=6 \mathrm{mH}$, capacitance $\mathrm{C}_{1}=200 \mu \mathrm{F}$; photovoltaic: active power $=0.6 \mathrm{~kW}$ temperature $=25^{0} \mathrm{C}$, irradiance $=1000 \mathrm{~W} / \mathrm{m}^{2}$; PMSG wind turbine active power $=0.6 \mathrm{~kW}$, voltage $=380 \mathrm{volt}, 50 \mathrm{~Hz}$, wind speed $=5 \mathrm{~m} / \mathrm{s}$, picth angle=2; PI controller: $\mathrm{K}_{\mathrm{p}}=0.2, \mathrm{~K}_{\mathrm{i}}=1.5$; fuzzy model: method=mamdani, composition=max-min; input membership function: error $\left(\mathrm{V}_{\mathrm{dc}}\right)=\operatorname{trapmf}$, trimf delta error $\left(\Delta \mathrm{V}_{\mathrm{dc}}\right)=\operatorname{trapmf}$, trimf; output membership function: $\bar{p}_{\text {loss }}=$ trapmf,trimf. 


\section{BIOGRAPHIES OF AUTHORS}

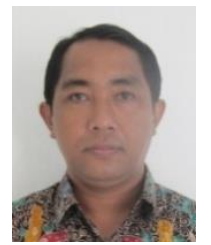

Amirullah was born in Sampang East Java Indonesia, in 1977. He received bachelor and master degree in electrical engineering from University of Brawijaya Malang and ITS Surabaya, in 2000 and 2008, respectively. He also worked as a lecturer in University of Bhayangkara Surabaya. He is currently working toward the doctoral degree, in electrical engineering in Power System and Simulation Laboratory (PSSL) ITS Surabaya. His research interest includes power distribution modeling and simulation, power quality, harmonics migitation, design of filter/PFC, and RE.

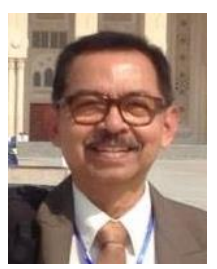

Ontoseno Penangsang was born in Madiun East Java Indonesia, in 1949. He received bachelor degree in electrical engineering from ITS Surabaya, in 1974. He received M.Sc and Ph.D degree in Power System Analysis from University of Wisconsin, Madison, USA, in 1979 and 1983, respectively. He is currently a professsor at Department of Electrical Engineering and the head of PSSL ITS Surabaya. He has a long experience and main interest in power system analysis (with renewable energy sources), design of power distribution, power quality, and harmonic mitigation in industry.

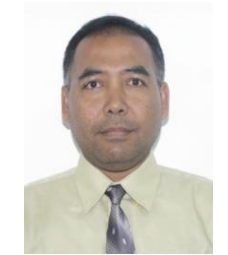

Adi Soeprijanto was born in Lumajang East Java Indonesia, in 1964. He received bachelor in electrical engineering from ITB Bandung, in 1988. He received master of electrical engineering in control automatic from ITB Bandung. He continued his study to Doctoral Program in Power System Control in Hiroshima University Japan and was finished it's in 2001. He is currently a professsor at Department of Electrical Engineering and member of PSSL in ITS Surabaya. His main interest includes power system analysis, power system stability control, and power system dynamic stability. He had already achieved a patent in optimum operation of power system. 